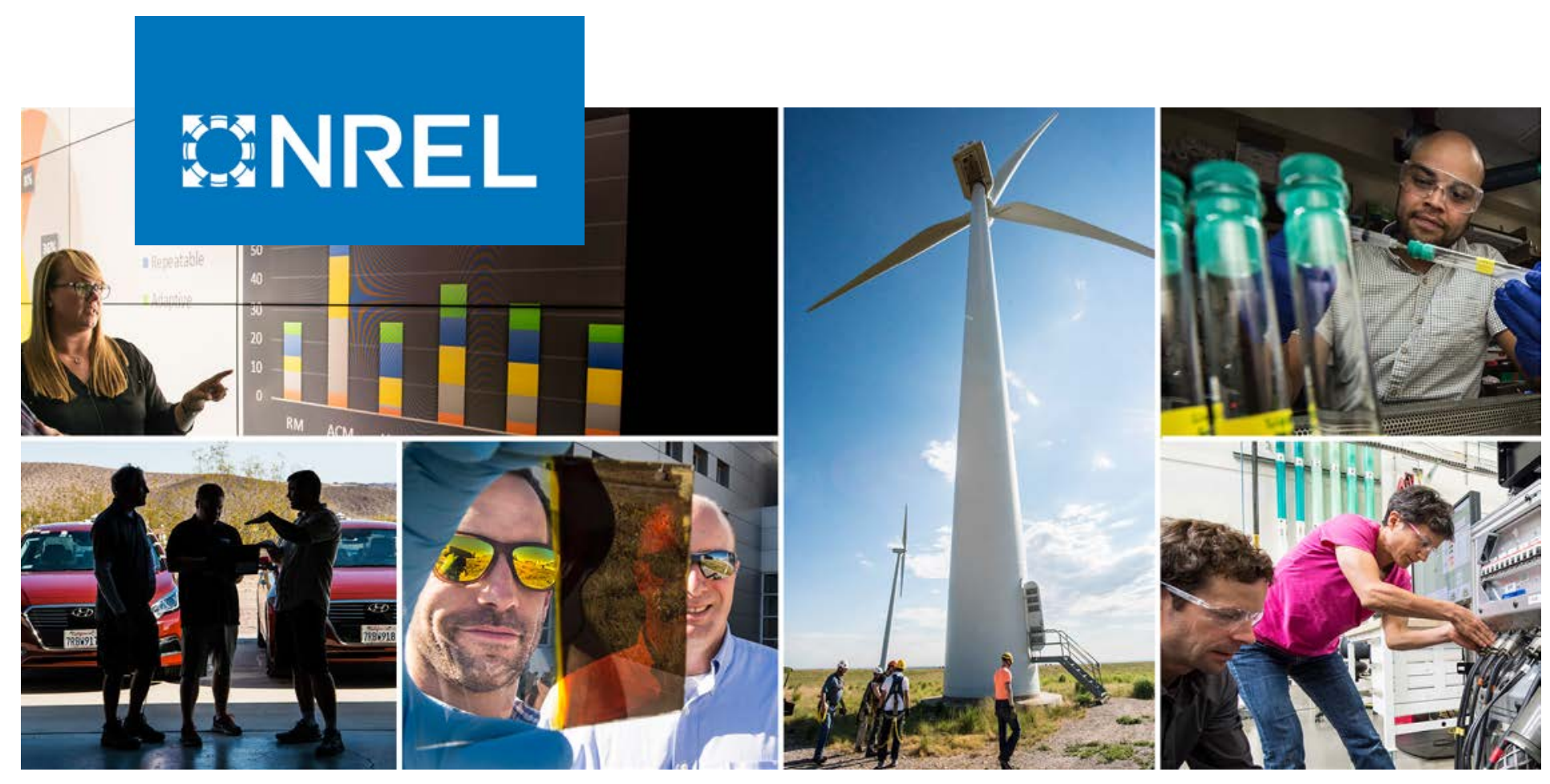

\title{
Energy Performance Validation of a Gaseous Air Cleaning Technology for Commercial Buildings
}

Michael Deru and Jason DeGraw

National Renewable Energy Laboratory

NREL is a national laboratory of the U.S. Department of Energy Office of Energy Efficiency \& Renewable Energy

Operated by the Alliance for Sustainable Energy, LLC

This report is available at no cost from the National Renewable Energy Laboratory (NREL) at www.nrel.gov/publications.
Technical Report

NREL/TP-5500-74545

February 2020 


\title{
EAREL
}

\section{Energy Performance Validation of a Gaseous Air Cleaning Technology for Commercial Buildings}

\author{
Michael Deru and Jason DeGraw
}

National Renewable Energy Laboratory

\section{Suggested Citation}

Deru, Michael, and Jason DeGraw. 2020. Energy Performance Validation of a Gaseous Air Cleaning Technology for Commercial Buildings. Golden, CO: National Renewable Energy Laboratory. NREL/TP-5500-74545. https://www.nrel.gov/docs/fy20osti/74545.pdf.

NREL is a national laboratory of the U.S. Department of Energy Office of Energy Efficiency \& Renewable Energy Operated by the Alliance for Sustainable Energy, LLC

This report is available at no cost from the National Renewable Energy Laboratory (NREL) at www.nrel.gov/publications.

Contract No. DE-AC36-08GO28308
Technical Report NREL/TP-5500-74545

February 2020

National Renewable Energy Laboratory 15013 Denver West Parkway Golden, CO 80401

303-275-3000 • www.nrel.gov 


\section{NOTICE}

This work was authored by the National Renewable Energy Laboratory, operated by Alliance for Sustainable Energy, LLC, for the U.S. Department of Energy (DOE) under Contract No. DE-AC36-08GO28308. Funding provided by the U.S. Department of Energy Office of Energy Efficiency and Renewable Energy Building Technologies Office. The views expressed herein do not necessarily represent the views of the DOE or the U.S. Government.

This report is available at no cost from the National Renewable Energy Laboratory (NREL) at www.nrel.gov/publications.

U.S. Department of Energy (DOE) reports produced after 1991 and a growing number of pre-1991 documents are available free via www.OSTI.gov.

Cover Photos by Dennis Schroeder: (clockwise, left to right) NREL 51934, NREL 45897, NREL 42160, NREL 45891, NREL 48097, NREL 46526.

NREL prints on paper that contains recycled content. 


\section{Acknowledgments}

The authors gratefully acknowledge the cooperation of the U.S. Department of Energy, the U.S. General Services Administration, enVerid, Morgan Stanley, University of Miami Health, University of Miami, Diplomat, and ArcBest in completion of this report. The authors would also like to acknowledge Ed Hancock, Greg Barker, and Paul Norton of Mountain Energy Partnership for their expertise in instrumentation and monitoring for this project.

This work was authored by the National Renewable Energy Laboratory, operated by Alliance for Sustainable Energy, LLC, for the U.S. Department of Energy (DOE) under Contract No. DEAC36-08GO28308. Funding provided by the U.S. Department of Energy Office of Energy Efficiency and Renewable Energy Building Technologies Office. The views expressed herein do not necessarily represent the views of the DOE or the U.S. Government. 


\section{Nomenclature or List of Acronyms}

$\begin{array}{ll}\text { AHU } & \text { air handling unit } \\ \text { CARB } & \text { California Air Resources Board } \\ \mathrm{CO}_{2} & \text { carbon dioxide } \\ \text { DOE } & \text { U.S. Department of Energy } \\ \text { HLR } & \text { HVAC Load Reduction } \\ \text { HVAC } & \text { heating, ventilating, and air conditioning } \\ \text { IAQ } & \text { indoor air quality } \\ \text { IAQP } & \text { Indoor Air Quality Procedure } \\ \text { IEQ } & \text { indoor environmental quality } \\ \text { M\&V } & \text { measurement and verification } \\ \text { NIOSH } & \text { National Institute for Occupational Safety and Health } \\ \text { NREL } & \text { National Renewable Energy Laboratory } \\ \text { OEHHA } & \text { Office of Environmental Health Hazard Assessment } \\ \text { OSHA } & \text { Occupational Safety and Health Administration } \\ \text { O\&M } & \text { operations and maintenance } \\ \text { ppb } & \text { parts per billion } \\ \text { ppm } & \text { parts per million } \\ \text { REL } & \text { reference exposure level } \\ \text { T } & \text { temperature } \\ \text { T\&RH } & \text { temperature and relative humidity } \\ \text { Tdry } & \text { dry bulb temperature } \\ \text { Twet } & \text { wet bulb temperature } \\ \text { VOC } & \text { volatile organic compounds } \\ \text { VRP } & \text { Ventilation Rate Procedure }\end{array}$




\section{Executive Summary}

The U.S. Department of Energy (DOE) Building Technologies Office Commercial Building Integration group conducts evaluations of new energy efficiency technologies as part of the High Impact Technology Catalyst program. The subject of this field validation project is an air cleaning technology that removes gaseous contaminants from indoor air to reduce outdoor air ventilation requirements. Reducing the volume of outdoor air required reduces heating, ventilating, and air conditioning (HVAC) loads and can provide significant energy savings for some buildings in certain climates. The technology, called the HLR (HVAC Load Reduction), was developed by enVerid. The technology uses a solid regenerable sorbent material that was developed by DOE's National Energy Technology Laboratory and licensed to the vendor for this application. The sorbent material was originally developed to adsorb carbon dioxide $\left(\mathrm{CO}_{2}\right)$; the vendor continued to develop the sorbent and the overall system so that it can also remove volatile organic compounds (including aldehydes), carbon monoxide, ozone, and particulate matter 2.5 micrometers in diameter or smaller $\left(\mathrm{PM}_{2.5}\right)$ from the air. This material has low regeneration temperature requirements, and its sorption properties are unaffected by humidity levels, both of which are beneficial for building applications.

Several buildings were considered for testing this technology; however, only three were included in the results. One of these test buildings experienced a significant increase in occupancy prior to the field test, and the original HVAC system was undersized and was unable to maintain adequate ventilation and temperature set points. However, the reduced ventilation requirements with the HLR systems allowed the HVAC system to meet indoor air quality requirements and maintain comfort conditions without expensive HVAC system upgrades. Energy savings in a Miami wellness center installation was measured to be $37 \%$ of the cooling energy during a 3month test period. The final installation was in a 42-story class-A office building in New York City. The energy savings from this building were $6 \%$ of the cooling energy. Savings during the heating season are also possible but were not included in this project. Energy modeling for medium-sized office buildings in five locations was used to show the impact of this technology in cooling and heating dominated locations. The annual energy cost savings ranged from $\$ 1,130$ to more than $\$ 3,500$, depending on ventilation reduction, location, and utility costs.

The savings are highly dependent on the ability to reduce outdoor air ventilation, HVAC equipment type and efficiency, and the climate in which the building is located. Each project should be evaluated for performance. This technology is applicable to retrofit projects and new construction. Application of this technology in new construction or major retrofits may allow for reduced HVAC system sizing, which may reduce overall system costs. Energy simulations of a medium office building estimated reductions in cooling capacity of $9 \%$ to $20 \%$, depending on the location. 


\section{Table of Contents}

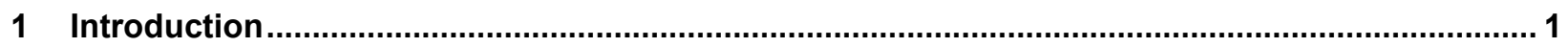

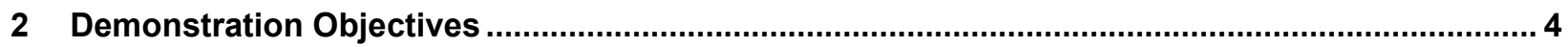

3 Site Selection

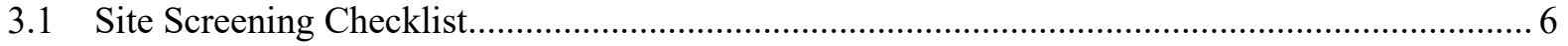

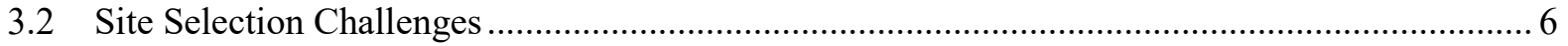

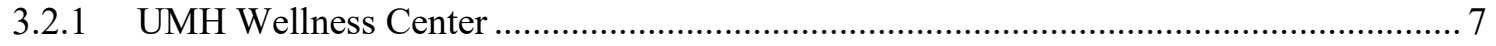

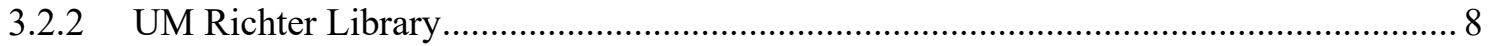

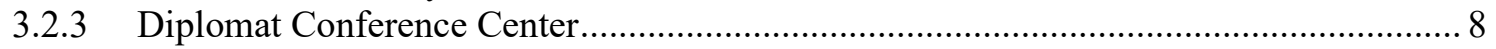

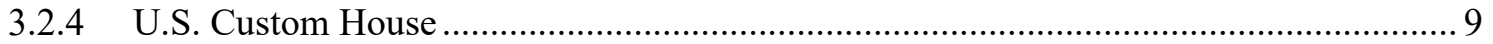

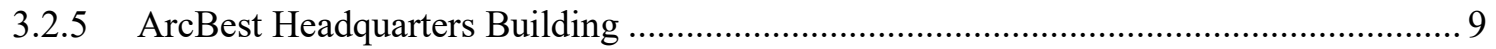

3.2.6 Morgan Stanley Headquarters Building ................................................................. 9

3.3 Lessons Learned in the Site Selection Process................................................................... 10

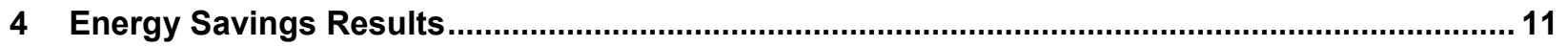

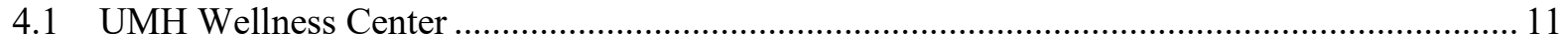

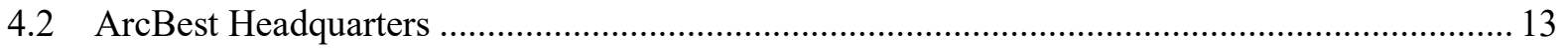

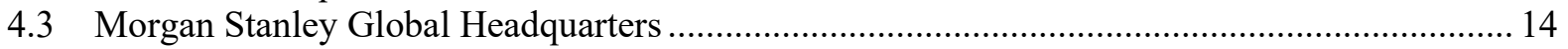

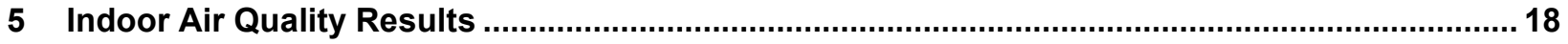

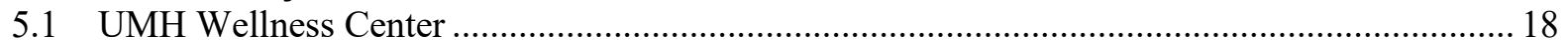

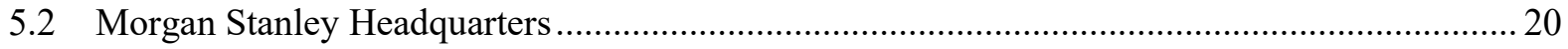

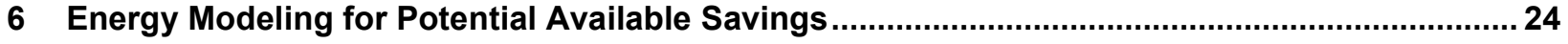

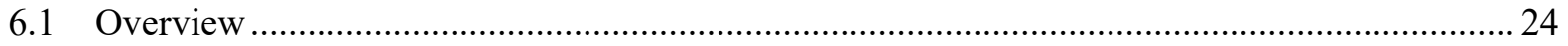

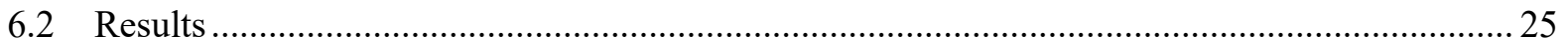

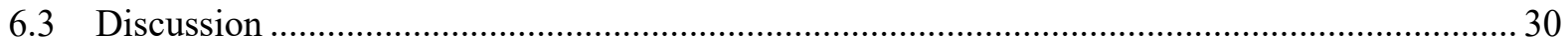

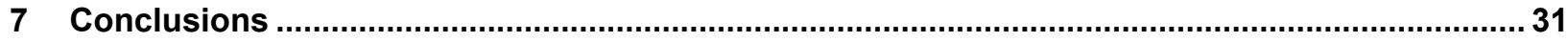

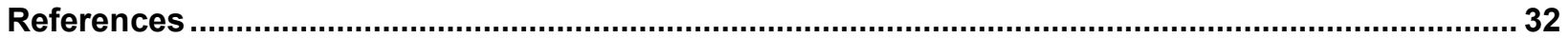

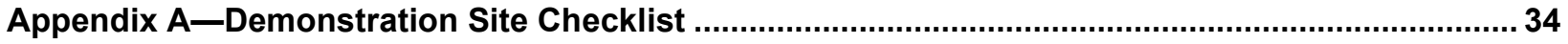

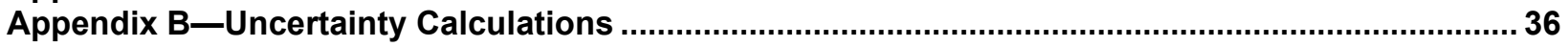

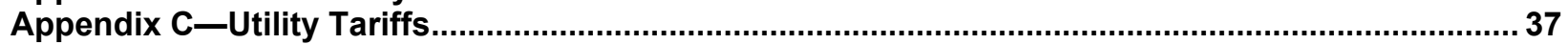




\section{List of Figures}

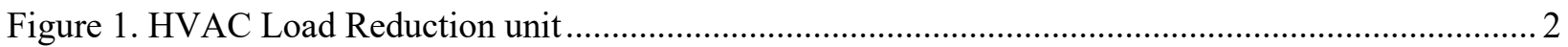

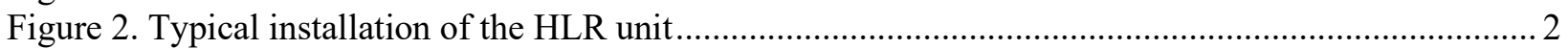

Figure 3. UMH chilled water energy for HLR ON and OFF operation................................................. 13

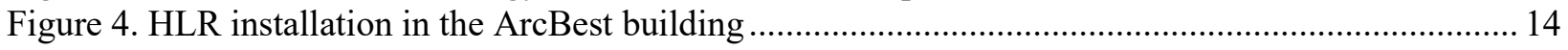

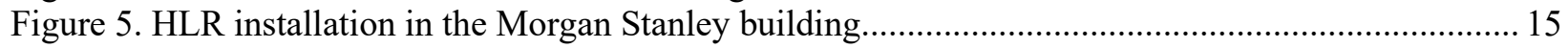

Figure 6. Morgan Stanley chilled water energy for HLR ON and OFF operation ................................. 16

Figure 7. UMH Wellness Center measurement and sampling locations.............................................. 20

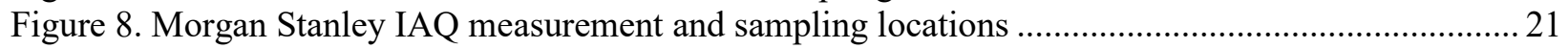

Figure 9. Miami cooling energy use by fraction of design outside air...................................................2 26

Figure 10. Chicago ventilation air heating energy use by fraction of design outside air .......................... 26

\section{List of Tables}

Table 1. Technology Performance Objectives, Metrics, and Data Requirements ................................... 5

Table 2. Buildings Under Consideration for Inclusion in the Project .................................................... 7

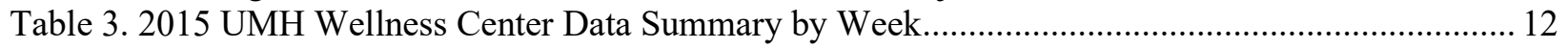

Table 4. 2016 UMH Wellness Center Data Summary by Week............................................................ 12

Table 5. Selected Contaminants of Concern for the UMH Wellness Center .......................................... 18

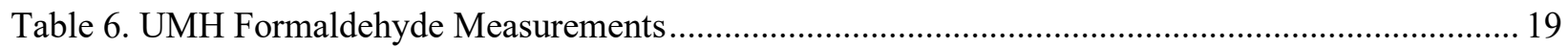

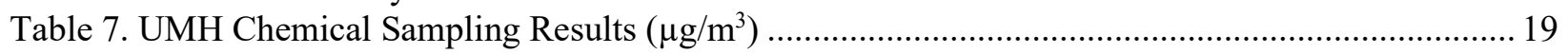

Table 8. Selected Contaminants of Concern for Morgan Stanley Building .............................................. 21

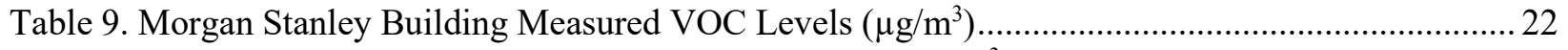

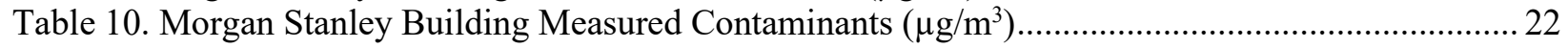

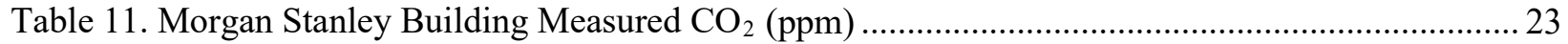

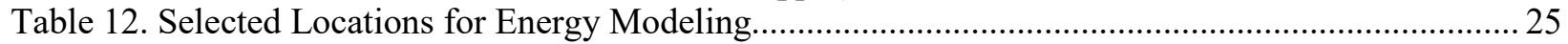

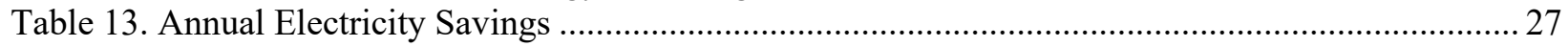

Table 14. Monthly Peak Demand (kW and \%) Reductions for One HLR Operation............................... 27

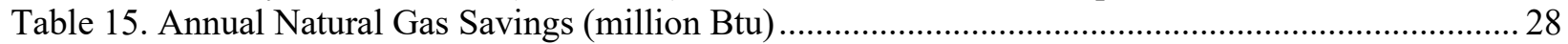

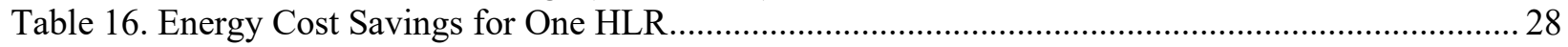

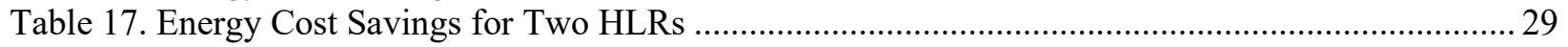

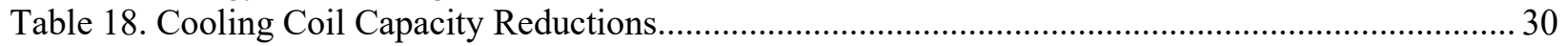

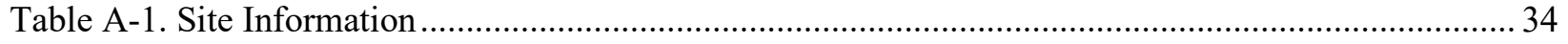

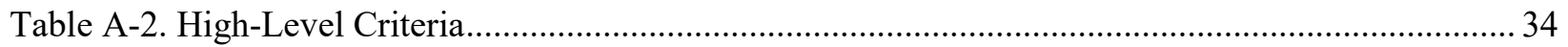

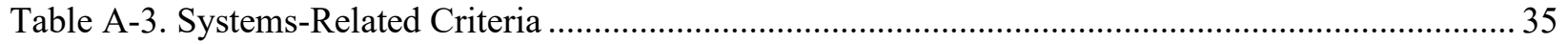

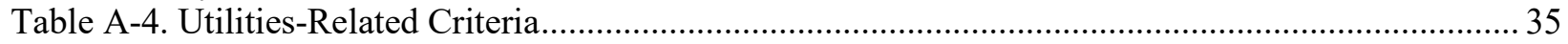

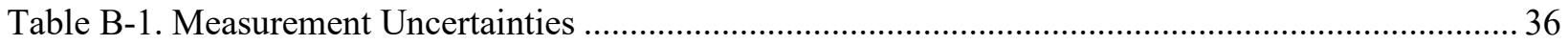




\section{Introduction}

This report documents a measurement and verification (M\&V) effort to quantify the benefits of an air cleaning technology developed by enVerid. This effort was funded as a U.S. Department of Energy (DOE) Building Technologies Office Commercial Building Integration technology demonstration project.

The subject of this validation project is an air cleaning technology that removes gaseous contaminants from indoor air with the intention of reducing outdoor air ventilation requirements. Reducing the volume of outdoor air can reduce heating, ventilating, and air conditioning (HVAC) loads required to condition this air and provide significant energy savings for buildings. The subject technology uses a solid regenerable sorbent material that was initially developed by DOE's National Energy Technology Laboratory and licensed to the vendor for this application. The sorbent material was originally developed to adsorb carbon dioxide $\left(\mathrm{CO}_{2}\right)$; the vendor has continued to develop the sorbent and the overall system so that it can also remove volatile organic compounds (VOCs) (including aldehydes), carbon monoxide, ozone, and particulate matter 2.5 micrometers in diameter or smaller $\left(\mathrm{PM}_{2.5}\right)$ from the air. The sorbent material has low regeneration temperature requirements, and its sorption properties are unaffected by humidity levels. Both characteristics are beneficial for building applications.

The technology, labeled HLR (HVAC Load Reduction), is implemented with compact modules that can be retrofitted into HVAC systems and integrated with new systems. The solid sorbents are contained in replaceable cartridges in a flexible design that is adaptable to different configurations. The cartridges are stacked in a v-bank configuration to maximize surface area utilization with minimum volume and pressure drop. Figure 1 shows the vertical configuration of the HLR module. The HLR module is designed for new construction and as a retrofit measure to central HVAC systems and is typically installed in the return airstream of a building HVAC system, as shown in Figure 2. The HLR is also compatible with plenum-return designs, in which one of more HLRs is installed in the return plenum. 


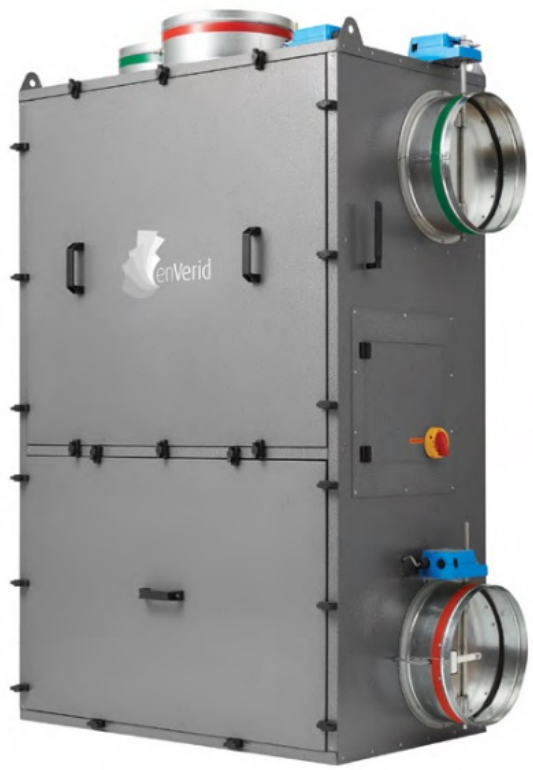

Figure 1. HVAC Load Reduction unit

Source: enVerid (2017)

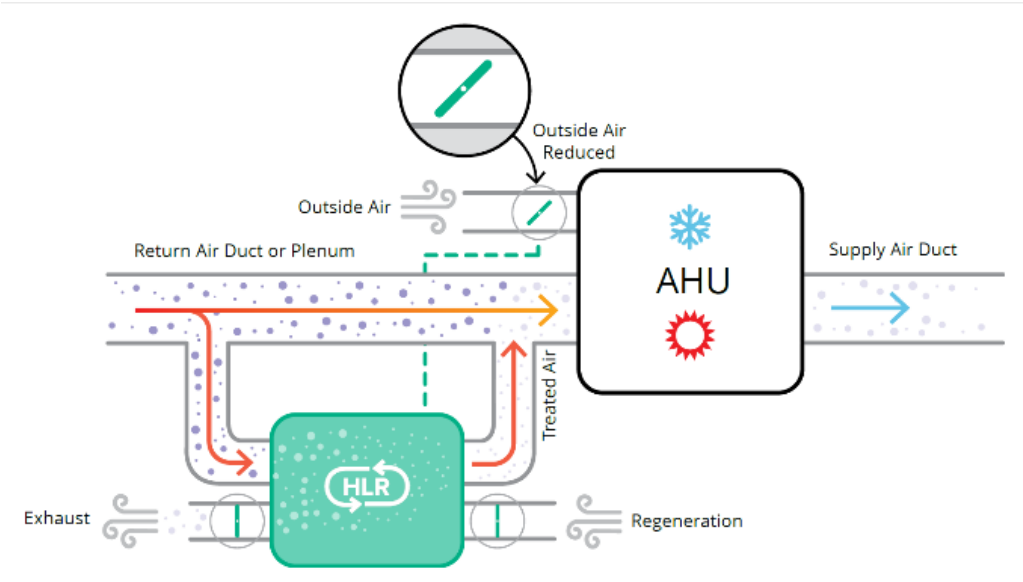

Figure 2. Typical installation of the HLR unit

Source: enVerid (2017)

The HLR operates in three modes - adsorption, regeneration, and standby. The HLR can be placed in standby mode when the building is unoccupied and during economizer mode when outdoor air quality is adequate for bringing into the building. During the adsorption mode, a fraction of the building return air is treated by the HLR to remove contaminants upstream of the air handling unit (AHU). The AHU outdoor air damper position is minimized to reduce the amount of outdoor air coming into the building and treated by the AHU. As the HLR treats the air, the contaminants accumulate in the sorbent material and the sorbent material must be regenerated to safely eliminate the contaminants. During the regeneration cycle, the HLR system is blocked from the building air system, and the cartridges are heated to $130^{\circ}-150^{\circ} \mathrm{F}$ for $30-60$ 
minutes to release the absorbed gases, which are exhausted to the ambient. Regeneration typically occurs once or twice every 24 hours and can be full or partial, depending on the timing of the space ventilation requirements and utility rates. The HLR unit monitors temperature, relative humidity, pressure across the cartridge bank, $\mathrm{CO}_{2}$, and total VOC, which can be used to determine when to regenerate, filtration effectiveness, and when it is time to replace the sorbent cartridges. For most cases, the vendor recommends annual replacement of the sorbent cartridges. 


\section{Demonstration Objectives}

The overall project objective is adapted from a vendor-provided Statement of Project Objectives:

The objective is to install and operate modular HLR retrofits in multiple and diverse buildings, monitor their performance, analyze the energy savings, evaluate the overall economics, and verify indoor environmental quality and indoor air quality (IEQ and IAQ) with specific tests for $\mathrm{CO}_{2}$ and other contaminants of concern (to be determined prior to demonstration initiation). The set of buildings selected for demonstration should collectively represent target markets based on market and commercialization analyses and strategies. The demonstration outcomes, if positive, will be developed into a body of validating case studies and data to encourage and enable widespread adoption around the country.

In support of the overall project objective, the National Renewable Energy Laboratory (NREL) focused on two technical performance objectives and four deployment-related objectives. The technical performance objectives are to:

1. Determine the energy performance and energy cost performance under HLR operation (compared to baseline operation without HLR)

2. Confirm that IEQ under HLR operation meets the requirements of ANSI/ASHRAE Standards 62.1-2016 (ASHRAE 2016) and 55-2017 (ASHRAE 2017).

The deployment-related objectives are to:

1. Identify and document the technical and practical challenges that emerge in design, installation, control, and operation of the HLR system

2. Document the level of occupant and maintenance staff satisfaction with the HLR system

3. Estimate the economic performance of the HLR system

4. Estimate the potential market impact and document potential challenges for wide-scale deployment of the HLR system.

Building on these objectives, Table 1 shows the general performance objectives, performance metrics, and data requirements for validation of this technology. These requirements were modified for each site to accommodate site-specific details. The specific indoor air contaminants of concern and performance targets were determined in coordination with subject matter experts. 
Table 1. Technology Performance Objectives, Metrics, and Data Requirements

\begin{tabular}{|l|l|l|l|}
\hline \multicolumn{1}{|c|}{$\begin{array}{c}\text { Technology } \\
\text { Performance } \\
\text { Objective }\end{array}$} & \multicolumn{1}{|c|}{$\begin{array}{c}\text { Performance } \\
\text { Metrics }\end{array}$} & $\begin{array}{c}\text { Preliminary } \\
\text { Performance Target }\end{array}$ & Data Requirements \\
\hline $\begin{array}{l}\text { Maintain acceptable } \\
\text { levels of specific } \\
\text { contaminants of } \\
\text { concern }\end{array}$ & TBD & TBD (site-specific) & $\begin{array}{l}\text { Short-term measurements of } \\
\text { specific contaminants }\end{array}$ \\
\hline $\begin{array}{l}\text { Maintain comfortable } \\
\text { indoor temperature and } \\
\text { relative humidity } \\
\text { (T\&RH) }\end{array}$ & T\&RH & $\begin{array}{l}\text { Within Standard 55 } \\
\text { comfort band }\end{array}$ & T\&RH from selected spaces \\
\hline $\begin{array}{l}\text { Reduce outdoor air } \\
\text { requirements }\end{array}$ & $\begin{array}{l}\text { Outdoor airflow } \\
\text { rate reductions }\end{array}$ & TBD (site-specific) & Outdoor airflow rates \\
\hline $\begin{array}{l}\text { Reduce energy } \\
\text { consumption for } \\
\text { treating outdoor air }\end{array}$ & $\begin{array}{l}\text { Daily chiller or } \\
\text { boiler energy } \\
\text { savings }\end{array}$ & TBD (site-specific) & Chiller and boiler energy \\
\hline $\begin{array}{l}\text { Maintain occupant } \\
\text { satisfaction }\end{array}$ & TBD & TBD & Occupant satisfaction surveys \\
\hline
\end{tabular}




\section{Site Selection}

This technology has the highest potential for savings in more extreme climates where heating or cooling the outdoor air is energy intensive. Climates with mild ambient conditions or many hours of potential economizing conditions may reduce the potential energy savings attributed to the HLR. Buildings such as schools, office buildings, assembly buildings, and retail buildings, which have high ventilation loads, may be good candidates. Health care facilities also have high ventilation loads, but they are very sensitive to IEQ and are less attractive as demonstration sites.

\subsection{Site Screening Checklist}

To quickly assess a candidate building for compatibility as a good demonstration site for this technology, a checklist was developed in consultation with the technology vendor to allow a building to be quickly evaluated. The checklist was not exhaustive and was not intended to definitively rule buildings into or out of the demonstration project; rather, the checklist was intended to provide a starting point for the evaluation. The full checklist is given in Appendix A. Some critical items are explained in detail below.

- Owner is ready to move, interested in making the demonstration a success-This technology demonstration takes considerable time and access to the building HVAC systems and potentially occupants, and a disinterested owner/operator of the building would make some aspects of this technology difficult to implement and assess.

- Outdoor air dampers are operable and can be controlled by the HLR system-Inoperable dampers or lack of control over the outdoor air that is introduced into the building reduces the degree to which this technology can create savings;

- Outdoor airflow rates $>20 \%$ of total airflow rates - Low outdoor air percentages mean that there is less savings available, effectively putting a cap on the savings that are possible. The $20 \%$ level is an approximate value and individual cases should be evaluated for potential energy savings.

- Available TAB report (vintage) - Availability of testing, adjusting, and balancing reports for the building indicates some awareness of the air distribution performance of the building (at least historically). An old report or no report would require the project to obtain a report or otherwise assess the performance of the air distribution systems. Understanding the air balance in the building and the amount of the outdoor airflow rate that can be reduced while still maintaining positive pressure in the building will determine the expected energy (and cost) savings and is essential for site evaluation.

- Building ventilation challenges (known IAQ issues, etc.) - While the technology may improve IAQ, this demonstration is primarily concerned with energy savings while maintaining acceptable IAQ, not energy savings while correcting poor IAQ. This distinction is important, as ANSI/ASHRAE Standard 62.1 lays out the conditions for acceptable IAQ, and "improvement" of air quality is inherently subjective and difficult to assess when individual occupants may assess the same conditions very differently.

\subsection{Site Selection Challenges}

Site selection can be a challenging process, and this was particularly true in this project. Many potential buildings were not suitable due to one or more issues brought out in the process of 
filling out the site screening checklist, and for unforeseen reasons that are detailed in Section 3.3. The buildings that were seriously considered for inclusion in the demonstration are listed in Table 2. Several of buildings that were initially selected for inclusion in the project later presented challenges to successful demonstration of the technology. Ultimately, these issues resulted in some buildings being dropped from the study in various stages of installation.

Table 2. Buildings Under Consideration for Inclusion in the Project

\begin{tabular}{|c|c|c|}
\hline Building & High-Level Description & Installation Status \\
\hline $\begin{array}{l}\text { University of Miami Health } \\
\text { (UMH) Wellness Center }\end{array}$ & $\begin{array}{l}\text { Two floors on the top of an 11- } \\
\text { story parking garage in Miami, } \\
\text { Florida }\end{array}$ & Installed and operating \\
\hline $\begin{array}{l}\text { University of Miami (UM) Richter } \\
\text { Library }\end{array}$ & $\begin{array}{l}\text { Nine-story library building on the } \\
\text { UM campus in Miami, Florida }\end{array}$ & $\begin{array}{l}\text { Installed on a portion of the } \\
\text { building but not included in the } \\
\text { demonstration }\end{array}$ \\
\hline Diplomat Conference Center & $\begin{array}{l}\text { Large conference center located } \\
\text { on the Atlantic coast of Florida }\end{array}$ & $\begin{array}{l}\text { Installed but not operated due to } \\
\text { building operation challenges }\end{array}$ \\
\hline U.S. Custom House & $\begin{array}{l}\text { Four-story historic building in } \\
\text { downtown Houston, Texas }\end{array}$ & $\begin{array}{l}\text { Installed and operated, but } \\
\text { removed due to HVAC system } \\
\text { operation challenges }\end{array}$ \\
\hline ArcBest Headquarters Building & $\begin{array}{l}\text { Five-story office building in Fort } \\
\text { Smith, Arkansas }\end{array}$ & Installed and operating \\
\hline Google Boston Office Building & $\begin{array}{l}\text { Medium-rise office building in } \\
\text { Boston, Massachusetts }\end{array}$ & $\begin{array}{l}\text { Installation completed but not } \\
\text { included in DOE study }\end{array}$ \\
\hline $\begin{array}{l}\text { Morgan Stanley Headquarters } \\
\text { Building }\end{array}$ & $\begin{array}{l}\text { High-rise office building with } \\
24 / 7 \text { occupancy located in New } \\
\text { York City }\end{array}$ & Installed and operating \\
\hline 500 Park & $\begin{array}{l}\text { Mid-rise mixed-use building } \\
\text { located in New York City }\end{array}$ & $\begin{array}{l}\text { Not selected due to unique } \\
\text { HVAC configuration }\end{array}$ \\
\hline
\end{tabular}

\subsubsection{UMH Wellness Center}

The UMH Wellness Center occupies the top two floors of a 13-story building, totaling approximately $60,000 \mathrm{ft}^{2}$ of space. The first 11 stories are a parking garage. The building is located next to a clinical research building and is connected by a walkway on the $12^{\text {th }}$ floor. The building is adjacent to a major roadway that experiences regular high traffic and congestion. The center includes open and closed workout rooms, offices, a large lobby area with (at the time of the initial site evaluation) a small food service area, and a treatment-size pool (not included in this demonstration). The center is served by four air handling systems and a pool dehumidification system. The AHUs are connected to a central chilled water system that serves the medical campus.

Several serious issues were identified during the initial site visit, including irregular occupancy, pressurization problems in the whole building (a significant breeze was noted in the connecting walkway) and in the pool area (airflow at doorways was out of the pool area), and inoperable outdoor air dampers. Significant corrosion froze the dampers in the closed position, resulting in make-up air being supplied through connection to the adjacent building. Communication with the vendor and the building owner indicated that the issues would be fixed prior to 
commencement of data collection. The pool dehumidification system was brought back into working order, and the whole building pressurization was addressed by repairing the outdoor air dampers. During the technology validation, it was found that facilities personnel modified the positions of the dampers (and broke one of the damper actuators during the first summer of operation), resulting in compromised performance data during portions of the demonstration. These periods of abnormal operation are noted in the results section.

\subsubsection{UM Richter Library}

The Richter Library is the University of Miami's main library. Built in the 1960s, the stacks are contained in a nine-story section of the building, while a three-story section houses offices and study areas. The building is served by at least five HVAC systems. Most of the stacks (on stories four through nine) are served by a single large AHU located on the ninth floor. A small AHU is used to maintain conditions in a rare books section on the eighth floor. Two AHUs serve most of the three-story section. A mezzanine area is served by another older HVAC system. These systems are connected to the campus chilled water system. The building is centrally located on the main University of Miami campus and is not close to major roadways.

The building was selected as a demonstration site, but subsequent issues with the systems serving the three-story section required further investigations. Eventually it was determined that faults with these AHUs (including a fan installed backwards) required that this portion of the building be dropped from the demonstration. The stacks section of the building is of less interest because the lower occupancy and irregular frequency of occupancy, so the building was not included in the demonstration project.

\subsubsection{Diplomat Conference Center}

The Diplomat Beach Resort is in Hollywood, Florida, and opened in 2002. The central building is 39 stories with 998 guest rooms, and a conference center occupies 200,000 $\mathrm{ft}^{2}$ in an adjacent building. The complex is positioned between the Atlantic Ocean and the Stranahan River and is not close to high-traffic roadways.

The conference center complex is conditioned with 10 AHUs and chilled water from a central chilled water plant that serves the entire property. The demonstration project focused on the conference center portion of the site and chilled water flow rate and temperatures supplied to the conference center were monitored. HLR systems were installed on all 10 AHUs for the demonstration project.

After installation, commissioning, and monitoring started, it was determined that the operation of the building prevented normal HLR operation and realization of savings. Several doors facing the ocean side of the property were routinely held open, resulting in a situation in which the outdoor air was uncontrolled. Additionally, kitchen ventilation problems led to issues with pressurization. When these items were discussed with the building owner, it became clear that, for business reasons, the operation of the ocean facing doors could not be changed, and the kitchen ventilation problems were likely to continue. As a result, the building was dropped from this project. 


\subsubsection{U.S. Custom House}

The U.S. Custom House is a four-story historical building located in downtown Houston, Texas. Construction of the building was completed in 1911, and the building has seen several configurations and tenant arrangements. The roadways surrounding the building are multilane city streets that see significant traffic at times.

The building is served by four AHUs, three in the penthouse and one in the basement. An HLR was installed on each of the AHUs and operation was initiated in July 2016; however, lower than expected savings results led to an investigation of the building systems and it was determined that the building was not operating in a manner consistent with current ANSI/ASHRAE Standard 62.1 requirements. In particular, the intentional outdoor airflows through the AHUs were measured to be less than the exhaust airflow, leading to negative building pressurization and uncontrolled outdoor airflows through other building openings. Further investigations by the building owner and the vendor failed to fully explain this and other anomalies in the behavior of the building. Measured energy savings in the building were marginal and within measurement uncertainty of no energy savings. As a result, the building was dropped as a demonstration site.

\subsubsection{ArcBest ${ }^{\circledR}$ Headquarters Building}

The ArcBest headquarters building is a $190,000 \mathrm{ft}^{2}$ five-story office building located in Fort Smith, Arkansas. The building serves as the headquarters of a logistics company and was originally designed for approximately 850 people. Due to expansion of the company, occupancy exceeded 1,000 people at the time of project initiation. The building is largely isolated from roadways by surrounding trees and hills. Each floor of the building is roughly divided into two wings (east and west) and served by two air handling units (one per wing). Chilled water is provided by two chillers located in a large mechanical room on the first floor. Heating is only required on the top floor, which is provided at terminal boxes on the fifth floor. 10 HLR units were installed for the five floors and two wings.

After this building was selected as a demonstration site, it was determined that the existing HVAC system was unable to operate in a manner that is consistent with ANSI/ASHRAE Standard 62.1. The existing mechanical systems did not have sufficient capacity to handle the building loads and condition the outdoor air required for the increased occupancy, resulting in uncomfortable conditions during the peak heating and cooling seasons. This situation created a problem for $\mathrm{M} \& \mathrm{~V}$, as it was not possible to establish a credible baseline performance and calculate energy savings. Even though no energy savings could be measured, this building was included in the demonstration project to understand the impact on building performance with undersized HVAC.

\subsubsection{Morgan Stanley Headquarters Building}

The Morgan Stanley headquarters building is a 1.3-million $\mathrm{ft}^{2}, 42$-story building located on Times Square in New York City. Most of the building has typical office occupancy and schedules; however, portions of the building have high internal loads and are occupied 24 hours a day, seven days a week. The building is served by 16 AHUs and four chillers located in mechanical rooms on the $7^{\text {th }}$ and $28^{\text {th }}$ floors. The size and complexity of the systems and controls in the building make the M\&V more difficult, but the ready availability of data from the building automation system somewhat made up for the added complexity. 
The large mechanical rooms act as return air plenums where return air from multiple ducts is mixed with outdoor air before being introduced to the supply air fans. The large mixing plenum provides an easy location for installation of the HLRs. 40 HLRs (20 in each mechanical room) were installed in four clusters of 10 with a common exhaust header for each cluster. The operation of the HLR clusters is sequenced to provide continuous air cleaning when needed and to avoid adding to the building peak electricity demand.

\subsection{Lessons Learned in the Site Selection Process}

The primary lesson learned in the course of the site selection process is that most owners and operators of buildings do not fully understand the operation of the ventilation system in their buildings. This finding is similar to those in the literature that building owners and operators often think their building is preforming much better than it is in relation to energy use and efficiency (Granade et al. 2009). This discrepancy is partially explained by the difficulty in measuring outdoor air flow and frequent problems with outdoor air dampers. While there are almost always locations where total flow can be measured (e.g. a sufficiently long run of main supply duct), few of the buildings had locations where outdoor air is easily and safely measured. Proper maintenance and operation of all dampers in a building is also challenging, especially for buildings in humid climates.

Additional lessons learned in the process include:

- Coordination between the owner and operations staff is crucial to the proper functioning of the technology and is as important to the success of the technology as physical aspects of the building.

- Many building operators in humid climates have, for lack of a better term, an "outdoor air strategy" that they use to deal with issues relating to outdoor air and humidity. It can be difficult to change this strategy, as the operators have often worked to mitigate impacts of humidity on buildings and are reluctant to change when their strategy is working.

- Potential commissioning issues should not be underestimated, even in buildings that have been operating for a long time, ostensibly without difficulty. Control and equipment installation issues can persist for long periods undetected. 


\section{Energy Savings Results}

One of the challenges of assessing the energy impacts of technological interventions in real buildings is the lack of directly comparable data. More specifically, the conditions during the baseline period cannot be reproduced exactly for the test period. It is thus necessary to find ways to compare data collected under different conditions to assess the impact of the technology on energy consumption. The standard method is to collect weather, energy, and building condition data under the same operating control for the baseline and test periods then adjust the results for variations in the uncontrolled variables (ASHRAE 2014 and IPVMP 2017).

The data that are available and not compromised are analyzed using multiple linear regression analysis, computed using the statistical software R. In mathematical terms, the model is written as:

$$
y=f\left(x_{1}, \ldots, x_{n}\right)=\beta_{0}+\beta_{1} x_{1}+\cdots+\beta_{n} x_{n}+\varepsilon
$$

where $y$ is the modeled quantity, $x_{1}, \ldots, x_{n}$ are measured variables, the $\beta_{0}, \ldots, \beta_{n}$ are model coefficients, and $\varepsilon$ is the error of fit. In this case, the modeled quantity is chilled water energy use and the measured variables are quantities such as dry bulb temperature, wet bulb temperature or relative humidity, weekday, and technology status. Weekday (taking values Sunday, Monday, Tuesday, and so on) and technology status (taking the value on or off) are called categorical variables and are a crucial component to the analysis. For longer data sets, experience indicates that the month may be needed to get good statistical models, so the model for the energy is:

$$
\text { energy }=f\left(T_{d r y}, T_{w e t}, \text { Weekday, Month,Status }\right)
$$

Energy savings are then computed as the difference between the models with the HLR units off and the model with the HLR units on.

$$
\begin{aligned}
\text { savings }=f( & \left(T_{d r y}, T_{\text {wet }} \text { Weekday, Month, Status }=\text { Off }\right) \\
& -f\left(T_{d r y}, T_{\text {wet }}, \text { Weekday, Month, Status }=0 \mathrm{On}\right)
\end{aligned}
$$

The final reported value is a percentage savings computed from summations of the savings and the chilled water energy over the measurement time period.

\subsection{UMH Wellness Center}

Data for UMH included hourly chilled water energy from University of Miami building management system; dry bulb temperature, dew point temperature, relative humidity, and wind speed from an NREL-installed weather station on the roof of the wellness center; and HLR status from enVerid. Wet bulb temperature was calculated from the dry bulb temperature and relative humidity. The regression models were developed with daily total chilled water energy and daily average temperature data. Energy consumption of the HLR units was not included in this analysis but is included in the simulated performance in Section 6.

As noted in Section 3, the UM Wellness Center presented several challenges as a demonstration site. Data were ostensibly collected over three cooling seasons, but the data from all three seasons were compromised for one reason or another. The issues over the first two years of the 
project period are described in Table 3 and Table 4. In these tables, the three installed HLRs are referred to as HLR2, HLR3, and HLR4 corresponding to AHUs 2, 3, and 4. AHU 1 is a much smaller unit and was not included in the project. The HLR units were cycled on and off weekly starting on Sunday to create alternating operation periods.

Table 3. 2015 UMH Wellness Center Data Summary by Week

\begin{tabular}{|c|c|c|c|c|c|c|c|c|c|c|c|c|c|c|}
\hline & June & \multicolumn{4}{|c|}{ July } & \multicolumn{5}{|c|}{ August } & \multicolumn{4}{|c|}{ September } \\
\hline Date & 28 & 5 & 12 & 19 & 26 & 2 & 9 & 16 & 23 & 30 & 6 & 13 & 20 & 27 \\
\hline $\begin{array}{l}\text { HLR } \\
\text { Status }\end{array}$ & \multicolumn{3}{|c|}{ Unknown } & \multicolumn{2}{|c|}{ On } & Off & On & Off & On & Off & On & Off & On & Off \\
\hline Data & \multicolumn{3}{|c|}{ No data } & \multicolumn{7}{|c|}{ Data begins $7 / 20$, Incorrect OAD position } & \multicolumn{4}{|c|}{ Data $9 / 1-$ end of season } \\
\hline Notes & & & & \multicolumn{7}{|c|}{$\begin{array}{l}\text { Chilled water energy savings computed as } \\
\sim 24 \% \text {. IAQ testing was conducted during this } \\
\text { time }\end{array}$} & \multicolumn{4}{|c|}{$\begin{array}{l}\text { Chilled water energy } \\
\text { savings calculations } \\
\text { result in low values } \\
(\sim 10 \%) \text {. OAD for HLR2 } \\
\text { is fixed at the open } \\
\text { position. Correct } \\
\text { operation of OADs for } \\
\text { HLR3 \& } 4\end{array}$} \\
\hline
\end{tabular}

Table 4. 2016 UMH Wellness Center Data Summary by Week

\begin{tabular}{|c|c|c|c|c|c|c|c|c|c|c|c|c|c|c|}
\hline & June & \multicolumn{5}{|c|}{ July } & \multicolumn{4}{|c|}{ August } & \multicolumn{4}{|c|}{ September } \\
\hline Date & 26 & 3 & 10 & 17 & 24 & 31 & 7 & 14 & 21 & 28 & 4 & 11 & 18 & 25 \\
\hline $\begin{array}{c}\text { HLR } \\
\text { Status }\end{array}$ & \multicolumn{2}{|c|}{ Mixed } & \multicolumn{2}{|c|}{ On } & \multicolumn{3}{|c|}{ Off } & \multicolumn{3}{|c|}{ On } & \multicolumn{3}{|c|}{ Off } & On \\
\hline Data & \multicolumn{7}{|c|}{ Data begins $6 / 28$, Incorrect Off OAD position } & \multicolumn{5}{|c|}{ Data 8/14-9/14 } & \multicolumn{2}{|c|}{ No data } \\
\hline Notes & \multicolumn{7}{|c|}{$\begin{array}{l}\text { Chilled water energy savings computed as } \\
\sim 6 \% .\end{array}$} & \multicolumn{5}{|c|}{$\begin{array}{c}\text { Chilled water energy savings } \\
\text { are } \sim 28 \% \text {. }\end{array}$} & & \\
\hline
\end{tabular}

For the first two years of the project, incorrect positioning of the damper systems resulted in approximately one calendar month of legitimate data (covering part of August and September of 2016). During this short period, approximately $28 \%$ chilled water energy savings were realized.

Results from 2017 were somewhat better, with available data running from June 22, 2017, through September 27, 2017. The HLRs operated 44 days and were off for 42 days, giving a nearly even split of the available days between technology operation and baseline operation. The daily chilled water energy along with the daily average ambient dry bulb temperature is shown in Figure 3. Only days with valid system operation and data collection are shown in the graph. The HLR OFF and HLR ON operation correspond with the change in outdoor air damper from fully open to minimum position for each AHU, which is what produces the energy savings. There is a clear relationship between chilled water energy consumption and the outdoor air damper position, and the estimated chilled water savings over this interval is estimated to be $37 \% \pm$ $14.5 \%$. 


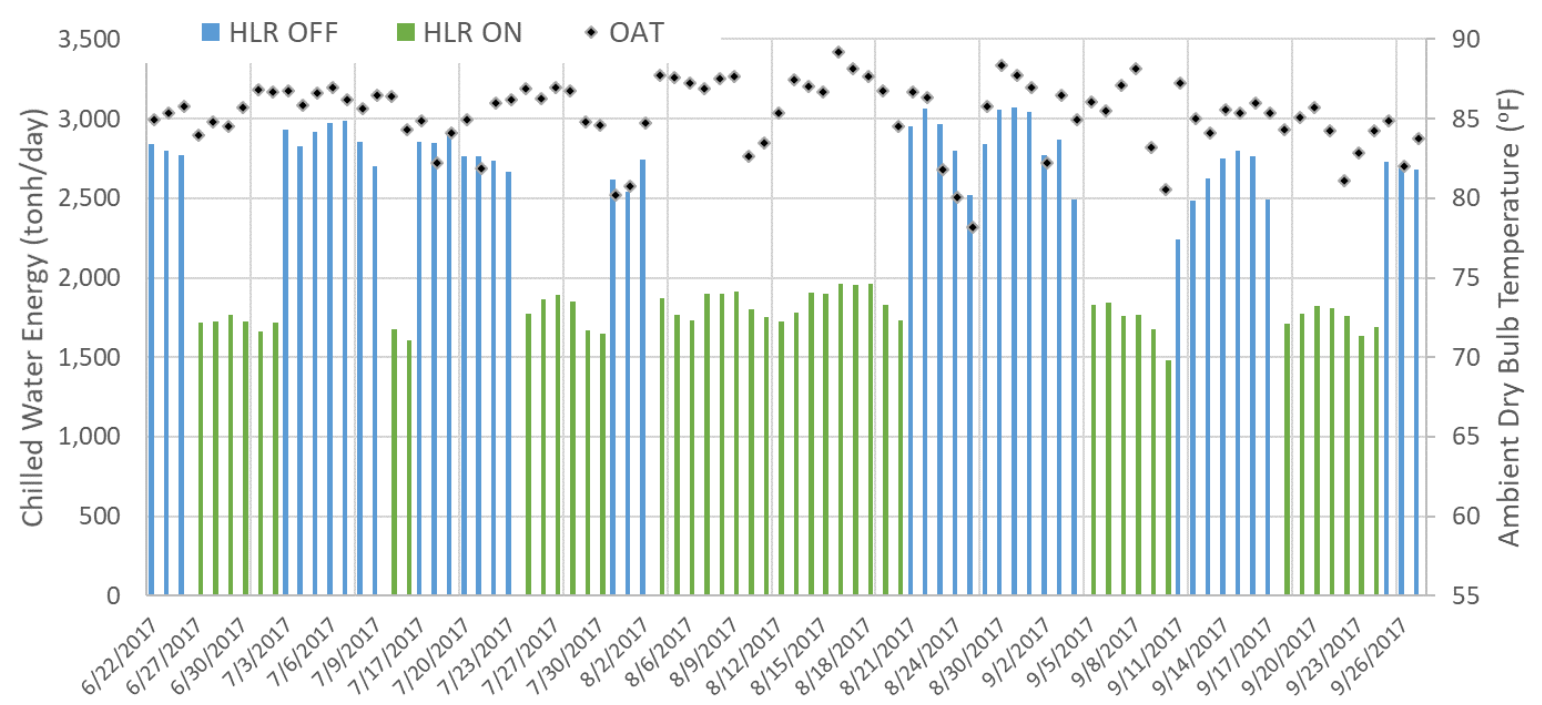

Figure 3. UMH chilled water energy for HLR ON and OFF operation

\subsection{ArcBest Headquarters}

The 10 HLRs installed in the ArcBest building (see Figure 4) allow the HVAC systems to be operated in a manner consistent with ANSI/ASHRAE Standard 62.1 Indoor Air Quality Procedure (IAQP) without additional capital expenses to increase the capacity of the mechanical systems. The reduction in outdoor airflow rate with the HLR operation reduced the peak cooling load by 273 tons. The expense of installing the HLRs was offset by the avoided cost of upgrading the building chillers, boilers, and AHUs and from energy and water savings. In addition, the HVAC systems are better able to satisfy the thermal conditioning requirements. Indoor air quality testing with the HLRs in operation showed that $\mathrm{CO}_{2}$, formaldehyde, and other contaminants of concern are maintained below acceptable exposure limits. While we were unable to estimate energy savings, this installation was successful in improving the IEQ and enabling the HVAC system to meet the demands of increased occupancy without upgrading system capacity. 


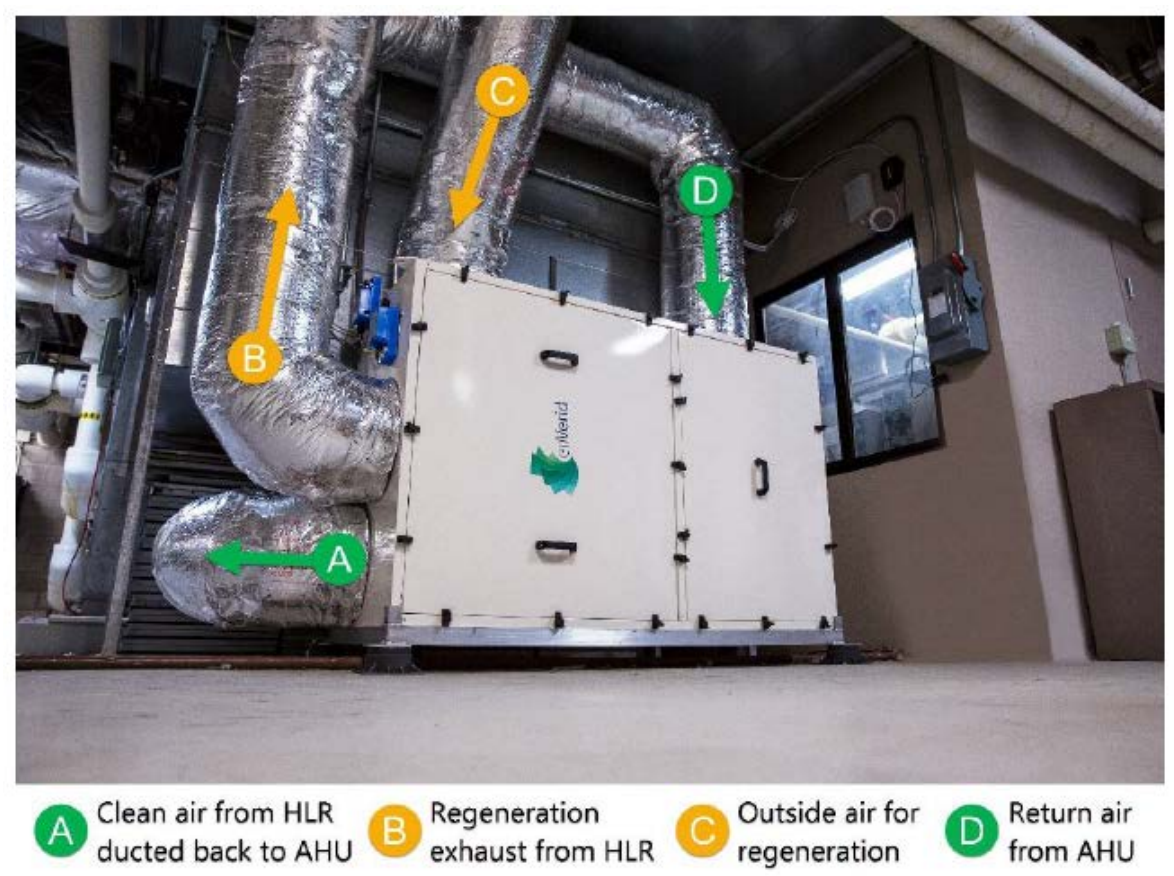

Figure 4. HLR installation in the ArcBest building

Source: enVerid

\subsection{Morgan Stanley Global Headquarters}

The Morgan Stanley building has four clusters of 10 HLR units installed in the mechanical rooms on the $7^{\text {th }}$ and $28^{\text {th }}$ floors. The installation of one of the four clusters is shown in Figure 5. The plenum return air enters the HLR at the bottom and the filtered air exits from the top of the HLR back into the return air plenum. This configuration provides potential for mixing of the filtered air from HLR with the return air, which would reduce the effectiveness of the HLRs. Detailed airflow modeling of this configuration and measurements of the inlet and outlet $\mathrm{CO}_{2}$ levels by the vendor predict that the short circuiting of airflow is small and is neglected in this analysis. 


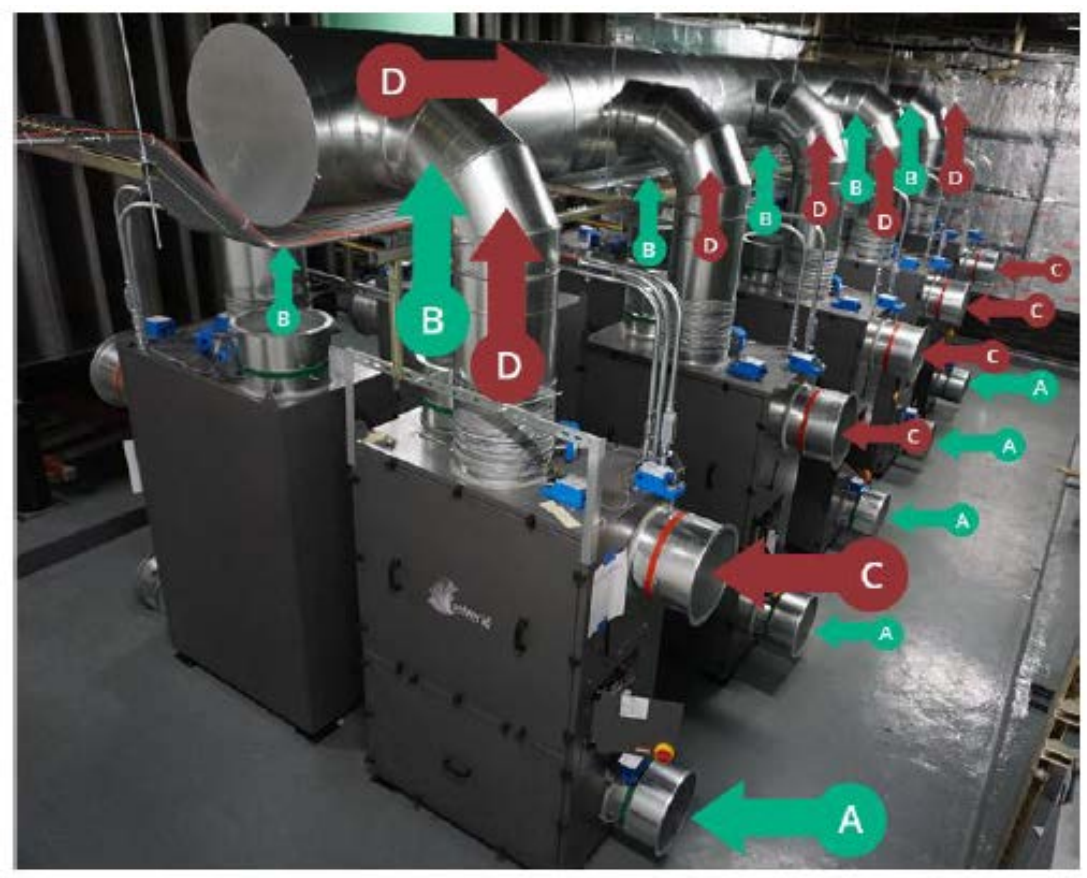

Return air
from Plenum B Clean air from HLR

(C) Plenum air fo

D Regeneration exhaust from HLR

Figure 5. HLR installation in the Morgan Stanley building

Source: enVerid

The airflow balance between the return, supply, exhaust, and ventilation airflow rates is determined by the pressure balance driven by multiple return, supply, and exhaust fans and the return and outdoor air damper positions. It is a complicated system and difficult to measure or estimate the flow rates accurately. The initial design called for $14 \%$ outdoor air during normal operation. Airflow measurements were taken by a testing and balancing contractor on May 17, 2017 , for three of the air systems on the $7^{\text {th }}$ floor and one air system on the $28^{\text {th }}$ floor. These measurements were used to determine damper positions for HLR ON and OFF operations and to estimate the outdoor airflow rates. From measurements on one seventh floor system, it was determined that the percent outdoor airflow rate is $13 \%$ for HLR OFF and $3.5 \%$ for HLR ON operation. This equates to an approximate change in outdoor airflow rate of 4,000 cfm between HLR OFF and HLR ON operation.

HLR operation in this building began on June 12, 2017, and chilled water energy data was supplied starting July 17, 2017. Operational testing and damper adjustments continued through August 8, 2017. Daily chilled water energy with HLR ON and OFF operation along with the outdoor air temperature for weekdays only are shown in Figure 6. The air-side economizer operated for 6 days in September, and the HLR units were turned off during these days. The outdoor air temperature varies significantly during this period making it difficult to visually see a correlation of energy consumption with HLR operation. 


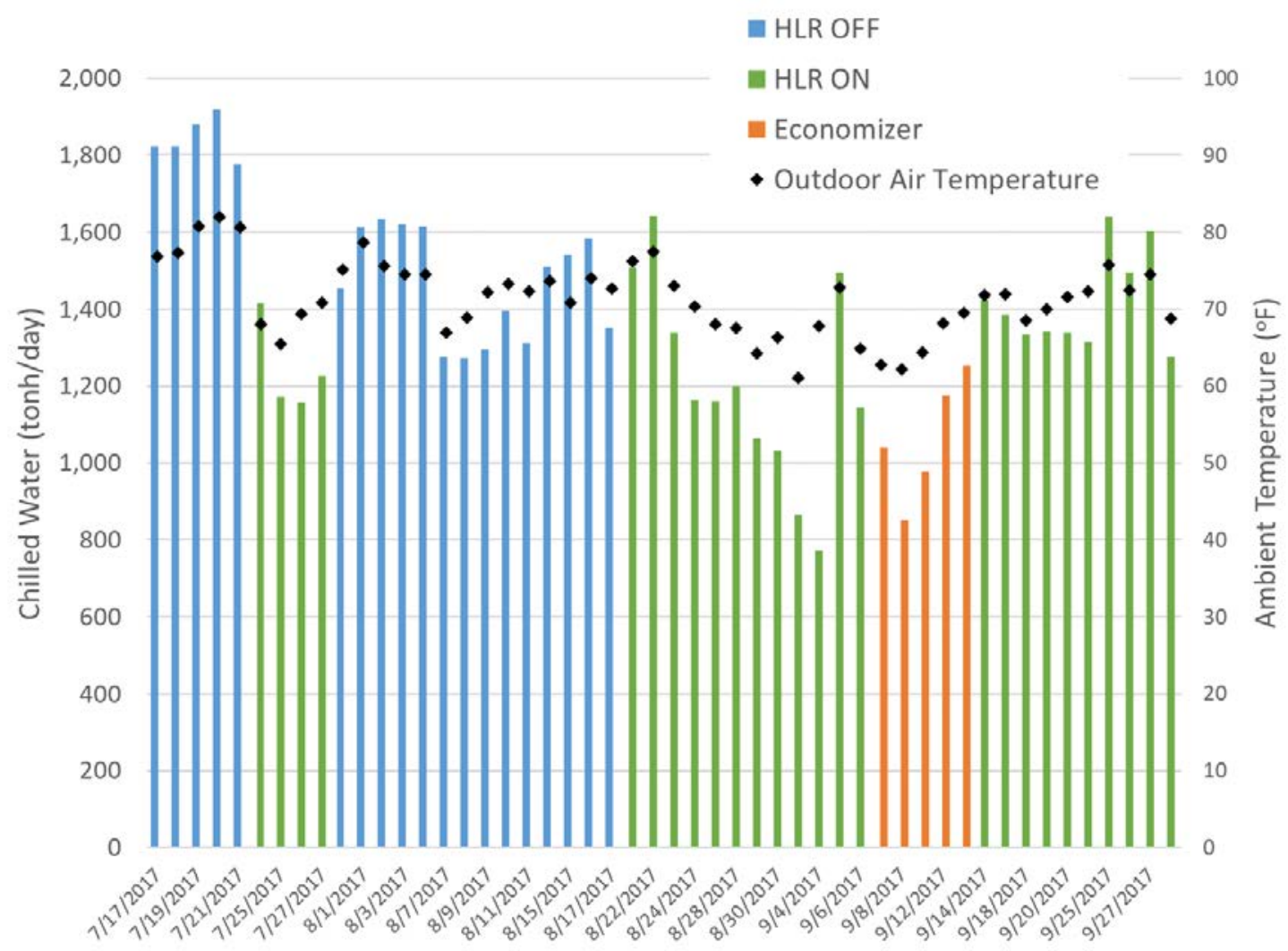

Figure 6. Morgan Stanley chilled water energy for HLR ON and OFF operation

The available data for model development are ambient dry bulb temperature, ambient relative humidity, chilled water supply and return temperatures, chilled water flow rates, and damper positions from the Morgan Stanley building automation system and HLR status from enVerid. The air-side economizer operated for six days in September, and the HLRs were turned off. These six days were not included in the regression model analysis. Multiple regression models to predict chilled water energy consumption were developed with different combinations of these variables including subsets of days. The best regression model based on highest coefficient of determination $\left(\mathrm{R}^{2}\right)$ was based on the HLR status, ambient dry bulb temperature, and ambient relative humidity covering the entire period of data collection. For the period of July 17, 2017, to September 28, 2017, the estimated energy savings are:

Percent chilled water energy savings $=5.8 \% \pm 2.5$

HLR energy consumption was not measured and was not included in this analysis, which would reduce the energy savings. The modeled energy performance in Section 6 includes HLR energy consumption. Measurement uncertainty is calculated using the quantities indicated in Appendix $\mathrm{B}$ and are propagated through the calculation procedure. This result indicates that operation of the technology is correlated with energy savings but at a smaller fraction of the total chilled water energy compared to the UMH Wellness center. Some of the difference may be explained by the cooler and less humid climate in New York, and by the lower fraction of the cooling load driven by the outdoor airflow rates in this building. 
Measurement of the heating season performance was planned but was unable to be determined because of challenges with operation during cold weather. The fans in the HLRs were unable to overcome the increased pressure drop in the exhaust duct work and a booster fan had to be installed. The booster fan was installed too late in the season to collect heating season performance. Heating system performance for multiple locations is included in the energy modeling in Section 6. 


\section{Indoor Air Quality Results}

An important component of this project was to demonstrate energy savings while maintaining acceptable indoor air quality. Data for this purpose was collected at both the UMH Wellness Center and the Morgan Stanley headquarters building.

\subsection{UMH Wellness Center}

In consultation with the vendor, six contaminants were selected as contaminants of concern, which are shown in Table 5 along with exposure limits. The maximum exposure limits are derived from a variety of sources listed in the table.

Table 5. Selected Contaminants of Concern for the UMH Wellness Center

\begin{tabular}{|l|c|l|}
\hline \multicolumn{1}{|c|}{ Contaminant } & Limit $\left(\boldsymbol{\mu g} / \mathbf{m}^{3}\right)$ & \multicolumn{1}{c|}{ Source } \\
\hline Formaldehyde & 33 & CARB \\
\hline Acetaldehyde & 140 & OEHHA (2018) Chronic REL \\
\hline d-limonene & $557 \times 10^{3}$ & OSHA (2018) target concentration \\
\hline Toluene & 300 & OEHHA (2018) Chronic REL \\
\hline Phenol & 200 & OEHHA (2018) Chronic REL \\
\hline Xylenes & 700 & OEHHA (2018) Chronic REL \\
\hline
\end{tabular}

To demonstrate that the ANSI/ASHRAE Standard 62.1 IAQP is satisfied, it must be established that each of these contaminants is controlled (i.e., kept below the limits in Table 5). Testing was conducted in 2015 during the time period in which the outdoor air damper positions were incorrect and in 2018 with correct outdoor air damper positioning. This testing is summarized in Table 6 and Table 7. The locations that measurements and samples were taken are shown in Figure 7.

The formaldehyde measurements summarized in Table 6 were taken by the vendor. Four of the five measurements with the HLR OFF exceeded the limit shown in Table 5. The measurements with the HLR ON were lower except for Location 1 and two measurements from 2015 were slightly above the limit of $33 \mu \mathrm{g} / \mathrm{m}^{3}$; however, the measurement taken in 2018 is below the limit for Location 3. The chemical sampling results summarized in Table 7 were collected by the vendor and the concentrations determined by a third-party laboratory. All contaminant concentrations are well below the target (high limit) values. For reference, the preinstall (HLR OFF) measurements are also presented in the table. 
Table 6. UMH Formaldehyde Measurements

\begin{tabular}{|c|c|c|c|}
\hline Location & $\begin{array}{c}\text { HLR OFF } \\
(\mathbf{3 / 2 4 / 2 0 1 5 )} \\
\left(\boldsymbol{\mu g} / \mathbf{m}^{3}\right)\end{array}$ & $\begin{array}{c}\text { HLR ON } \\
(\mathbf{8 / 2 8 / 2 0 1 5 )} \\
\left(\boldsymbol{\mu g} / \mathbf{m}^{3}\right)\end{array}$ & $\begin{array}{c}\text { HLR ON } \\
(\mathbf{9 / 2 0 / 2 0 1 8 )} \\
\left(\mathbf{\mu g} / \mathbf{m}^{3}\right)\end{array}$ \\
\hline 1 & 22.1 & 30.7 & \\
\hline 2 & 45.5 & 23.0 & \\
\hline 3 & 38.4 & 36.5 & 32 \\
\hline 4 & 67.2 & 19.2 & \\
\hline 5 & 44.2 & 25.0 & \\
\hline 6 & NA & 36.5 & \\
\hline
\end{tabular}

Table 7. UMH Chemical Sampling Results $\left(\mu \mathrm{g} / \mathrm{m}^{3}\right)$

\begin{tabular}{|c|c|c|c|c|}
\hline Compound & Target & $\begin{array}{c}\text { HLR OFF } \\
(4 / 23 / 2015)\end{array}$ & $\begin{array}{l}\text { HLR ON } \\
(8 / 13 / 2015)\end{array}$ & $\begin{array}{c}\text { HLR ON } \\
(9 / 20 / 2018)\end{array}$ \\
\hline Acetaldehyde & 140 & 25 & 21 & 27 \\
\hline Acetone & 500 & 12 & 15 & 28 \\
\hline Benzene & 3 & 0.6 & 1 & 0.9 \\
\hline 1,4-Dichlorobenzene & 800 & & & 0.3 \\
\hline Methylene Chloride & 400 & & & 0.3 \\
\hline Naphthalene & 9 & & & 0.2 \\
\hline Phenol & 10 & & & 0.5 \\
\hline Styrene & 900 & 0.5 & 0.8 & 0.4 \\
\hline Tetrachloroethene & 35 & & & 0.3 \\
\hline Toluene & 300 & 2.6 & 4.7 & 4.5 \\
\hline 1,1,1-Trichloroethane & 500 & & & $<0.2$ \\
\hline Xylenes & 500 & 3.6 & 3.8 & 4.1 \\
\hline Limonene & $557 \times 10^{3}$ & 140 & 330 & \\
\hline Total VOCs & & 850 & 1200 & 800 \\
\hline Ozone & 137 & & & 0.015 \\
\hline $\mathrm{PM}_{2.5}$ & 35 & & & 1 \\
\hline
\end{tabular}

Carbon dioxide measurements were also taken during the 9/20/2018 with the HLRs ON at sampling in Locations 1 and 4. The average measured $\mathrm{CO}_{2}$ levels in were 649 ppm and 752 ppm, respectively, which are well below the ambient concentration plus $500 \mathrm{ppm}$ and within the range of acceptable levels. 


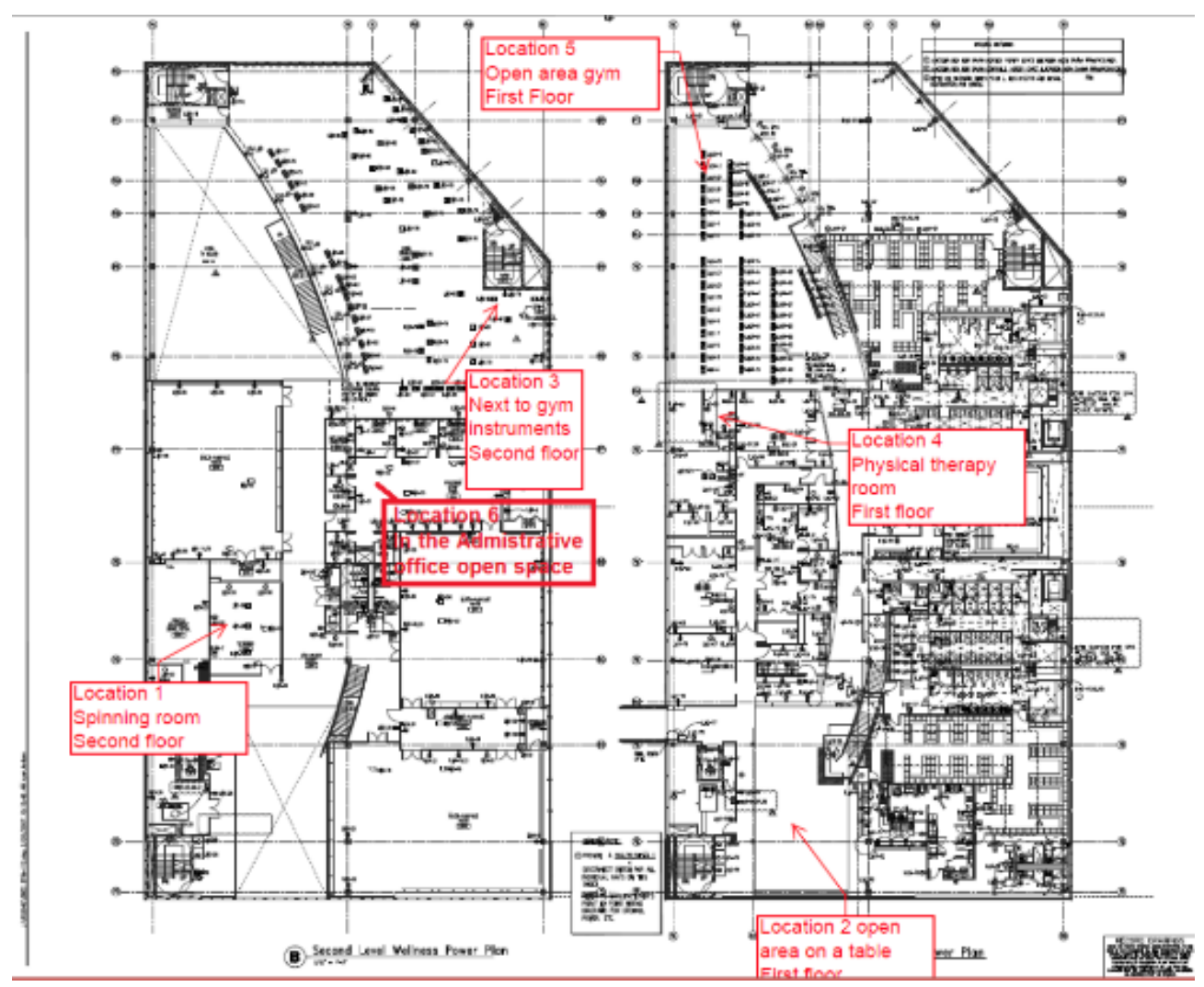

Figure 7. UMH Wellness Center measurement and sampling locations

Two issues with the data presented here must be noted. First, at the time of the 2015 measurements, there was a food service establishment located in the main lobby area (which moved out of the building before the 2016 cooling season). The food service operations introduced higher levels of VOCs and particulate matter to the indoor air based on the cooking and cleaning activities. Second, the data from 2015 are compromised (even if only a little) by the incorrect damper position. This issue prompted the final set of IAQ measurements taken in 2018 to show compliance with ANSI/ASHRAE Standard 62.1 IAQP.

An additional concern with the Wellness Center as a demonstration site is that levels and schedules of occupancy are insufficient to provide adequate occupant evaluation of the effectiveness of the technology; however, the available IAQ data tend to indicate that requirements of ANSI/ASHRAE Standard 62.1 are being met.

\subsection{Morgan Stanley Headquarters}

In consultation with the vendor, seven contaminants were selected as contaminants of concern along with exposure limit values as shown in Table 8 . The first four are primarily generated from indoor sources, and the final three are primarily from outdoor sources for this location. 
Table 8. Selected Contaminants of Concern for Morgan Stanley Building

\begin{tabular}{|c|c|l|}
\hline Contaminant & Limit $\left(\boldsymbol{\mu g} / \mathbf{m}^{3}\right)$ & \multicolumn{1}{|c|}{ Source } \\
\hline Formaldehyde & 33 & CARB \\
\hline Acetaldehyde & 140 & OEHHA (2018) Chronic REL \\
\hline Toluene & 300 & OEHHA (2018) Chronic REL \\
\hline Xylenes & 700 & OEHHA (2018 Chronic REL \\
\hline Ozone & 196 & NISOSH 2018 \\
\hline PM $_{2.5}$ & 12 & EPA 2013 \\
\hline PM $_{10}$ & 150 & EPA 2013 \\
\hline
\end{tabular}

To demonstrate that the ANSI/ASHRAE Standard 62.1 IAQP is satisfied, it must be established that each of these contaminants are controlled (i.e., kept below the limits in Table 8) with the HLR units ON. Testing was completed by the vendor and by a third party contracted by Morgan Stanley. Testing was completed in six locations on the $4^{\text {th }}, 16^{\text {th }}$, and $30^{\text {th }}$ floors, as shown in Figure 8.
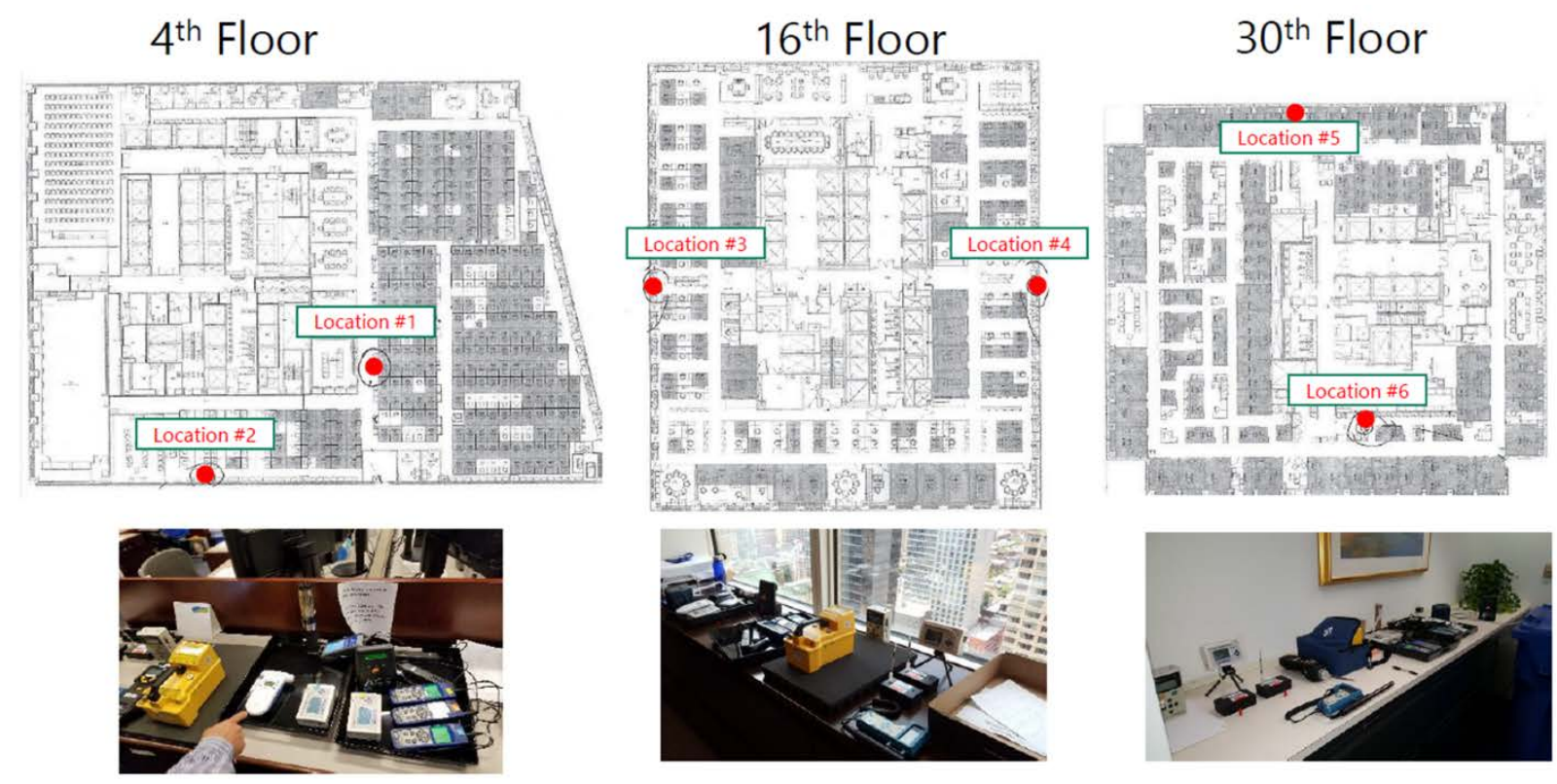

Figure 8. Morgan Stanley IAQ measurement and sampling locations

Source: enVerid

The results of the IAQ testing are shown in Table 9 and Table 10. These numbers represent the average concentration over an eight-hour period. All the measurements are below the concentration limits established in Table 8 and therefore satisfy the requirements for ANSI/ASHRAE Standard 62.1-2016 IAQP. The measurements taken with the HLR OFF are not required per the IAQP but are included here for reference. The outside levels for the contaminants that are primarily sourced from outside are also shown in Table 10. 
Table 9. Morgan Stanley Building Measured VOC Levels $\left(\mu \mathrm{g} / \mathrm{m}^{3}\right)$

\begin{tabular}{|l|c|c|c|c|c|c|c|c|}
\hline \multicolumn{1}{|c|}{ Location } & \multicolumn{2}{|c|}{ Formaldehyde } & \multicolumn{2}{c|}{ Acetaldehyde } & \multicolumn{2}{c|}{ Toluene } & \multicolumn{2}{c|}{ Xylenes } \\
\hline \multicolumn{1}{|c|}{ HLR Status } & OFF & ON & OFF & ON & OFF & ON & OFF & ON \\
\hline 4th floor, location \#1 & 22.5 & 18.4 & 12.0 & 9.3 & 37.0 & 5.9 & 11.3 & 2.6 \\
\hline 4th floor, location \#2 & 17.2 & 17.9 & 9.0 & 12 & 22.0 & 7.7 & 10.0 & 2.6 \\
\hline 16th floor, W location \#3 & 17.3 & 18.0 & 17.0 & 9.7 & 3.7 & 5.5 & NA & 3.0 \\
\hline 16th floor, E location \#4 & 19.4 & 21.3 & 8.0 & 6.0 & 4.9 & 4.6 & 3.0 & 2.6 \\
\hline 30th floor, location \#5 & 15.0 & 18.3 & 12.0 & 8.4 & 5.0 & 6.2 & 2.8 & 2.3 \\
\hline 30th floor, location \#6 & 20.0 & 21.4 & 7.0 & 7.0 & 8.5 & 6.0 & 4.2 & 2.7 \\
\hline
\end{tabular}

Table 10. Morgan Stanley Building Measured Contaminants $\left(\mu \mathrm{g} / \mathrm{m}^{3}\right)$

\begin{tabular}{|l|c|c|c|c|c|c|}
\hline & \multicolumn{2}{|c|}{ Ozone } & \multicolumn{2}{c|}{ PM $_{2.5}$} & \multicolumn{2}{c|}{ PM10 } \\
\hline \multicolumn{1}{|c|}{ Location/HLR Status } & OFF & ON & OFF & ON & OFF & ON \\
\hline 4th floor, location \#1 & 0 & 0 & 1 & NA & 4 & NA \\
\hline 4th floor, location \#2 & 3 & 0 & 1 & NA & 3 & NA \\
\hline 16th floor, W location \#3 & 15 & 1 & 1 & NA & 4 & NA \\
\hline 16th floor, E location \#4 & 4 & 0 & 1 & 1 & 5 & 4 \\
\hline 30th floor, location \#5 & 8 & 2 & 1 & 0 & 5 & 5 \\
\hline 30th floor, location \#6 & 3 & 0 & 1 & 0 & 2 & 2 \\
\hline W. 47 th St. sidewalk & 20 & NA & 12 & NA & 92 & NA \\
\hline 7th floor, OA plenum & 150 & NA & 4 & NA & 25 & NA \\
\hline
\end{tabular}

The $\mathrm{CO}_{2}$ measurements with HLR OFF and HLR ON operation are shown in Table 11 . The $\mathrm{CO}_{2}$ concentrations increased with the HLR ON in all locations except for \#1; however, the outdoor air $\mathrm{CO}_{2}$ concentration was slightly higher during the HLR ON operation, and all readings are less than $500 \mathrm{ppm}$ above the outdoor air $\mathrm{CO}_{2}$, which is well within the range of acceptable levels. 
Table 11. Morgan Stanley Building Measured $\mathrm{CO}_{2}$ (ppm)

\begin{tabular}{|l|c|c|}
\hline & \multicolumn{2}{|c|}{ CO $_{\mathbf{2}}$} \\
\hline \multicolumn{1}{|c|}{ Location / HLR Status } & OFF & ON \\
\hline 4th floor, location \#1 & 754 & 741 \\
\hline 4th floor, location \#2 & 780 & 866 \\
\hline 16th floor, W location \#3 & 736 & 869 \\
\hline 16th floor, E location \#4 & 597 & 827 \\
\hline 30th floor, location \#5 & 787 & 961 \\
\hline 30th floor, location \#6 & 790 & 968 \\
\hline W. 47th St. sidewalk & NA & 536 \\
\hline 7th floor, OA plenum & 453 & 476 \\
\hline
\end{tabular}




\section{Energy Modeling for Potential Available Savings}

\subsection{Overview}

The deployment-based results described above show a positive correlation between installation of the technology and energy savings. To better assess the potential for energy savings for other locations, a modeling study was completed using EnergyPlus ${ }^{\circledR}$ energy modeling software (version 9.0.1) with typical meteorological year (TMY3) data for six locations (DOE 2018a). For general results, the DOE prototype building model of a medium office building and compliant with energy efficiency ANSI/ASHRAE/IES Standard 90.1-2013 (ASHRAE 2013a) was used for the energy simulations (DOE 2018b).

The medium office building prototype model represents a "typical" medium office building with a 53,600 $\mathrm{ft}^{2}$ floor area and three floors. The HVAC system is representative of a packaged direct expansion air-conditioning unit with gas heating for each floor (three total) and terminal variable air volume boxes with electric heating coils in each zone. The gas heating is used for heating the outdoor air only, and the electric reheat provides zone heating to maintain comfort conditions. The ventilation flow rates are compliant with ANSI/ASHRAE Standard 62.1-2013 (ASHRAE $2013 \mathrm{~b}$ ), which is $1,520 \mathrm{cfm}$ per floor assuming an occupant density of $200 \mathrm{ft}^{2}$ per person. The model operates with 100\% ventilation 15 hours per day on weekdays, 11 hours on Saturday, and zero hours on Sundays and holidays. Exhaust is not explicitly modeled; however, it would be $300 \mathrm{cfm}$ per floor assuming there are three women's and three men's toilets per floor.

Some changes to the reference building models were made for these simulations. A supply air temperature reset with outdoor air temperature strategy was implemented in order to reduce excessive reheat energy in the perimeter zones. The model autosize feature was turned on for this exercise to properly account for sizing impacts of reducing the ventilation air.

To understand the impact of reducing the ventilation rate on building energy performance, five simulations were run for each location reducing the outdoor airflow rate from $100 \%$ to $20 \%$ in $20 \%$ steps during occupied hours. The outdoor airflow rate at $20 \%$ of the design value is slightly more than the exhaust floor rate to keep the building pressurized. The actual outdoor airflow rate should be kept at least $10 \%$ higher than the exhaust to maintain a positive pressure in the building.

The $20 \%$ ventilation rate case represents the typical application for the HLR technology for this building configuration. The HLR installation for each building must be designed for building AHU and ducting configuration. For this study, we consider cases for one and two HLR units. The HLR units are scheduled to run only when ventilation is $100 \%$ and off when the ventilation dampers are closed or when the ventilation system is in economizer mode. The HLR-1000 power levels are $0.288 \mathrm{~kW}$ in adsorption mode, $5 \mathrm{~kW}$ in regeneration mode, and less than $1 \mathrm{~W}$ in idle or standby mode (enVerid 2017). It was assumed that the HLR units run in adsorption mode during building ventilation operation, run 1 hour per day in regeneration mode for days with greater than five hours of adsorption run time, and are in standby mode when the building is unoccupied. The HLR units do not run when the HVAC system is in economizer mode.

The energy models were run in the six locations shown in Table 12 to represent a range of climates and show the impact in cooling and heating seasons. The cooling and heating degree 
days in the table were determined from TMY3 files. The energy models were run with actual utility rates from each city representative of commercial rates for a building of this size and are shown in Appendix C.

Table 12. Selected Locations for Energy Modeling

\begin{tabular}{|c|c|c|c|}
\hline Location & $\begin{array}{c}\text { Climate } \\
\text { Zone }\end{array}$ & $\begin{array}{c}\text { Cooling } \\
\text { Degree Days } \\
\text { Base } 50^{\circ} \mathrm{F} \\
\left(10^{\circ} \mathrm{C}\right) \\
{ }^{\circ} \mathrm{F}\left({ }^{\circ} \mathrm{C}\right)\end{array}$ & $\begin{array}{c}\text { Heating } \\
\text { Degree Days } \\
\text { Base } 50^{\circ} \mathrm{F} \\
\left(10^{\circ} \mathrm{C}\right) \\
{ }^{\circ} \mathrm{F}\left({ }^{\circ} \mathrm{C}\right)\end{array}$ \\
\hline Miami, FL & $1 \mathrm{~A}$ & $9,805(5,447)$ & $2(1)$ \\
\hline Houston, TX & $2 \mathrm{~A}$ & $7,277(4,043)$ & $218(121)$ \\
\hline Atlanta, GA & $3 A$ & $5,308(2,949)$ & $686(381)$ \\
\hline Las Vegas, NV & $3 B$ & $7,034(3,908)$ & 317 (176) \\
\hline New York, NY & $4 \mathrm{~A}$ & $3,812(2,118)$ & $1,732(962)$ \\
\hline Chicago, IL & $5 A$ & $3,355(1,864)$ & $2,792(1,551)$ \\
\hline
\end{tabular}

\subsection{Results}

The energy models were run for a full year with sub-hourly simulations in each location, and the total cooling energy and heating energy consumption by month and by ventilation reduction are shown in Figure 9 and Figure 10 for two locations. The cooling energy in Figure 9 is the total building cooling electricity consumption for Miami, while the heating energy in Figure 10 represents the natural gas consumption in Chicago for heating ventilation air only. Zone heating is accomplished by electric heating coils in the variable air volume boxes and is not affected by changes in the ventilation. These figures show the potential energy savings from ventilation reduction strategies for this building. As expected, the largest savings are during the months with the most extreme temperatures (and extreme humidity when cooling). The ventilation air heating energy drops to very low values in Chicago as the ventilation air volume is reduced to $40 \%$ and $20 \%$ of the design value. 


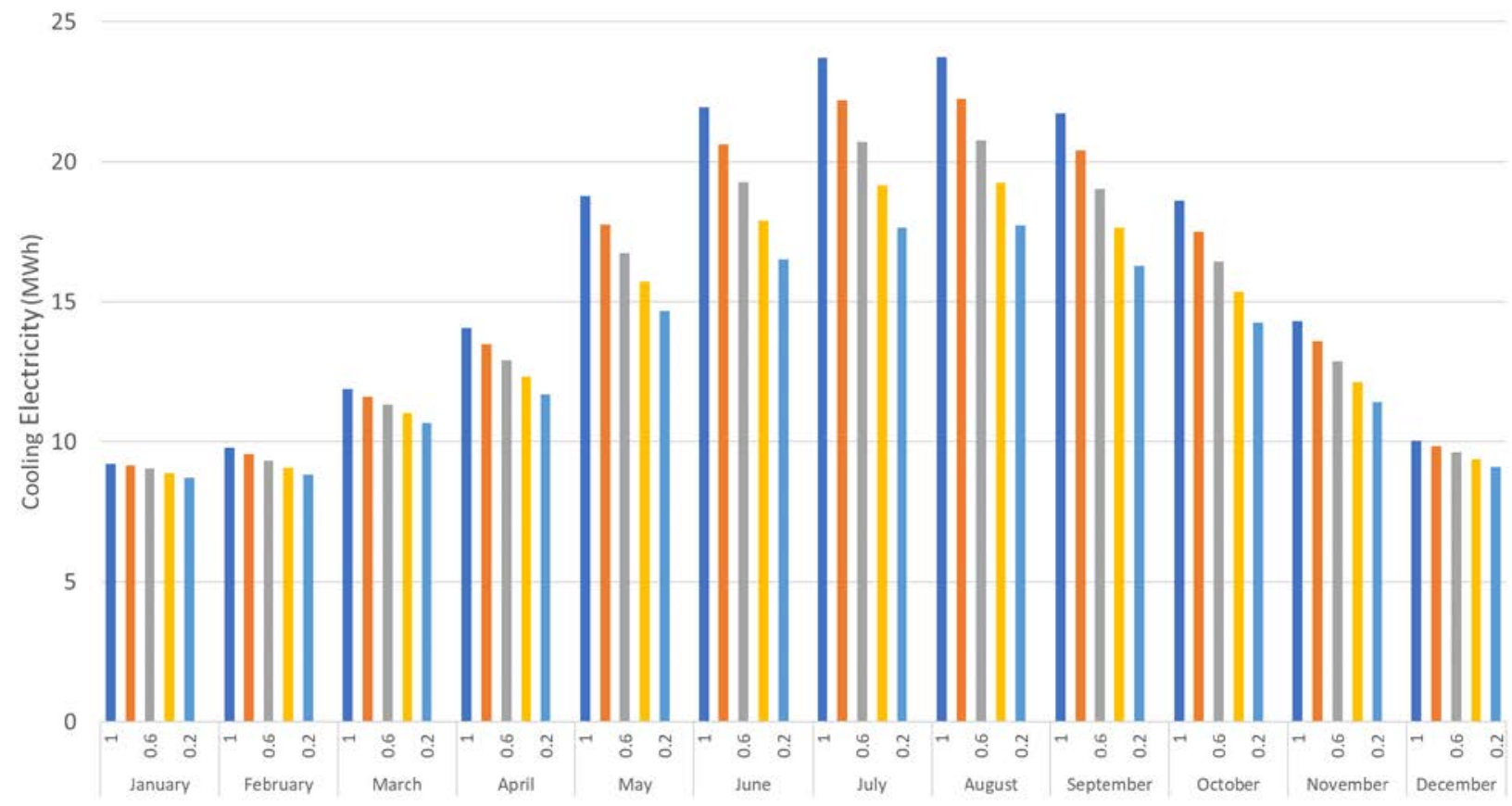

Figure 9. Miami cooling energy use by fraction of design outdoor air

60

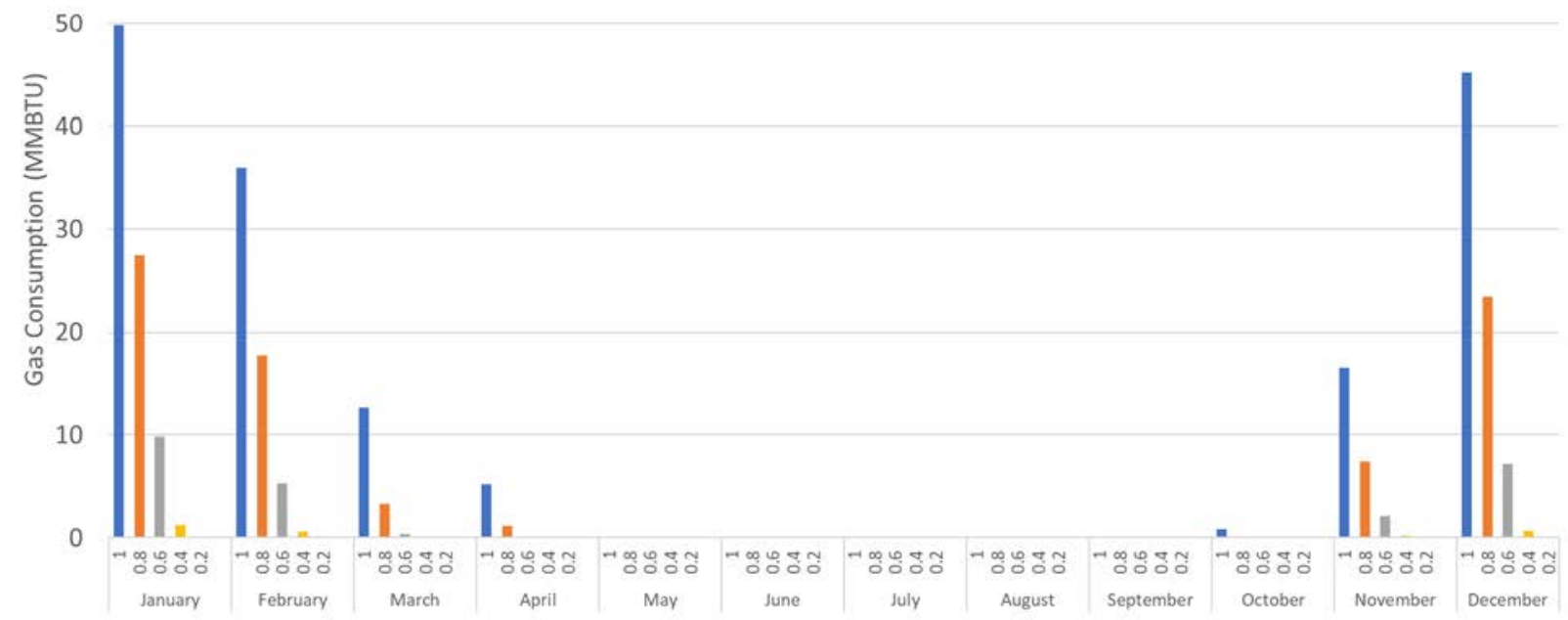

Figure 10. Chicago ventilation air heating energy use by fraction of design outdoor air

The annual total electricity savings for each location are shown in Table 13, the monthly electricity peak demand savings are shown in Table 14, and the annual natural gas energy savings are shown in Table 15. Fan energy consumption increases slightly in the lower ventilation cases, which is why the whole building electricity savings are slightly lower than the cooling electricity savings. Negative peak demand reductions shown in Table 14 are increases in whole building peak demand with the HLR operation. Advanced controls that limit peak demand through shifting of loads may be able to avoid these peak demands and improve the cost performance. The energy simulations predict a 100\% savings for heating gas consumption for all 
locations. Gas is only used for heating the ventilation air, space heating is controlled by electric reheat coils in this building model.

Table 13. Annual Electricity Savings

\begin{tabular}{|c|c|c|c|c|c|}
\hline \multirow{2}{*}{ Location } & \multirow{2}{*}{ Climate Zone } & \multicolumn{2}{|c|}{ Cooling } & \multicolumn{2}{c|}{ Whole Building } \\
\cline { 3 - 6 } & & $\begin{array}{c}\text { Savings } \\
\text { (MWh) }\end{array}$ & $\begin{array}{c}\text { Savings } \\
\text { (\%) }\end{array}$ & $\begin{array}{c}\text { Savings } \\
\text { (MWh) }\end{array}$ & $\begin{array}{c}\text { Savings } \\
\text { (\%) }\end{array}$ \\
\hline Miami, FL & $1 \mathrm{~A}$ & 40.3 & $20.4 \%$ & 37.8 & $6.8 \%$ \\
\hline Houston, TX & $2 \mathrm{~A}$ & 29.7 & $20.5 \%$ & 29.4 & $5.8 \%$ \\
\hline Atlanta, GA & $3 \mathrm{~A}$ & 15.6 & $16.0 \%$ & 16.8 & $3.6 \%$ \\
\hline Las Vegas, NV & $3 \mathrm{~B}$ & 11.3 & $9.4 \%$ & 11.4 & $2.3 \%$ \\
\hline New York, NY & $4 \mathrm{~A}$ & 8.8 & $12.0 \%$ & 8.2 & $1.8 \%$ \\
\hline Chicago, IL & $5 \mathrm{~A}$ & 4.7 & $6.6 \%$ & 3.8 & $0.8 \%$ \\
\hline
\end{tabular}

Table 14. Monthly Peak Demand (kW and \%) Reductions for One HLR Operation

\begin{tabular}{|c|c|c|c|c|c|c|}
\hline & Miami & Houston & Atlanta & Las Vegas & New York & Chicago \\
\hline January & $12.4(8.8 \%)$ & $30.5(17.9 \%)$ & $17.3(8.9 \%)$ & $7.3(5.4 \%)$ & $13.7(9.4 \%)$ & $5.4(2.5 \%)$ \\
\hline February & $7.1(5.4 \%)$ & $23.6(15.5 \%)$ & $25.0(12.4 \%)$ & $13.0(10.0 \%)$ & $20.6(15.9 \%)$ & $18.8(8.2 \%)$ \\
\hline March & $9.1(6.4 \%)$ & $1.9(1.5 \%)$ & $1.8(1.5 \%)$ & $1.8(1.6 \%)$ & $0.0(0.0 \%)$ & $-0.1(0.0 \%)$ \\
\hline April & $13.3(8.7 \%)$ & $7.6(5.7 \%)$ & $0.7(0.6 \%)$ & $2.4(1.8 \%)$ & $-0.1(-0.2 \%)$ & $7.4(5.0 \%)$ \\
\hline May & $11.5(7.2 \%)$ & $13.2(8.5 \%)$ & $7.9(5.6 \%)$ & $7.7(4.6 \%)$ & $2.4(2.9 \%)$ & $-1.5(-1.1 \%)$ \\
\hline June & $14.5(8.9 \%)$ & $14.2(8.5 \%)$ & $10.6(6.7 \%)$ & $8.4(4.5 \%)$ & $14.2(14.0 \%)$ & $-12.5(-7.4 \%)$ \\
\hline July & $16.1(9.1 \%)$ & $17.8(9.9 \%)$ & $13.8(8.0 \%)$ & $12.4(6.2 \%)$ & $10.9(11.2 \%)$ & $13.9(7.1 \%)$ \\
\hline August & $15.4(9.1 \%)$ & $17.5(9.2 \%)$ & $12.0(7.0 \%)$ & $8.9(4.7 \%)$ & $15.3(15.2 \%)$ & $-1.8(-1.0 \%)$ \\
\hline September & $15.5(9.3 \%)$ & $13.5(7.8 \%)$ & $12.1(7.5 \%)$ & $7.8(4.3 \%)$ & $6.2(6.9 \%)$ & $-12.5(-8.3 \%)$ \\
\hline October & $14.3(8.9 \%)$ & $15.6(10.3 \%)$ & $7.2(5.4 \%)$ & $5.3(3.6 \%)$ & $4.1(5.2 \%)$ & $-0.7(-0.6 \%)$ \\
\hline November & $12.1(8.3 \%)$ & $6.3(4.8 \%)$ & $3.0(2.6 \%)$ & $0.1(0.1 \%)$ & $1.2(1.5 \%)$ & $-0.6(-0.3 \%)$ \\
\hline December & $10.8(7.7 \%)$ & $20.5(14.5 \%)$ & $20.2(12.4 \%)$ & $2.2(1.8 \%)$ & $0.0(0.0 \%)$ & $2.9(1.4 \%)$ \\
\hline
\end{tabular}


Table 15. Annual Natural Gas Savings (million Btu)

\begin{tabular}{|c|c|c|c|c|c|}
\hline \multirow[b]{2}{*}{ Location } & \multirow{2}{*}{$\begin{array}{c}\text { Climate } \\
\text { Zone }\end{array}$} & \multicolumn{2}{|c|}{ Heating } & \multicolumn{2}{|c|}{ Whole Building } \\
\hline & & $\begin{array}{l}\text { Savings } \\
\text { (Therms) }\end{array}$ & $\begin{array}{c}\text { Savings } \\
(\%)\end{array}$ & $\begin{array}{l}\text { Savings } \\
\text { (Therms) }\end{array}$ & $\begin{array}{c}\text { Savings } \\
(\%)\end{array}$ \\
\hline Miami, FL & $1 \mathrm{~A}$ & 0.0 & $0 \%$ & 0.0 & $0 \%$ \\
\hline Houston, TX & $2 \mathrm{~A}$ & 277.6 & $100 \%$ & 277.6 & $28.0 \%$ \\
\hline Atlanta, GA & $3 A$ & 939.2 & $100 \%$ & 939.2 & $55.3 \%$ \\
\hline Las Vegas, NV & $3 B$ & 67.3 & $100 \%$ & 67.3 & $8.5 \%$ \\
\hline New York, NY & $4 \mathrm{~A}$ & 877.4 & $100 \%$ & 877.4 & $52.1 \%$ \\
\hline Chicago, IL & $5 \mathrm{~A}$ & 1662.4 & $100 \%$ & 1662.4 & $66.5 \%$ \\
\hline
\end{tabular}

The monthly and annual total utility cost savings are shown in Table 16 and Table 17 for one and two HLR operation. The energy impact of running two HLRs compared to one is small, but the payback period will be significantly shorter with the cost of only one HLR. In mild conditions, the energy cost for running the HLR units may exceed the energy cost savings, in which case, the HLR units should be turned off. In the energy simulations, determination of when to run the HLR units was determined monthly based on positive total energy cost savings. These results are representative for the assumptions and utility rates used in the simulations, actual results will vary depending on the building operation and utility rates.

Table 16. Energy Cost Savings for One HLR

\begin{tabular}{|c|c|c|c|c|c|c|}
\hline Month & Miami & Houston & Atlanta & Las Vegas & New York & Chicago \\
\hline January & $\$ 147$ & $\$ 274$ & $\$ 664$ & $\$ 93$ & $\$ 119$ & $\$ 258$ \\
\hline February & $\$ 115$ & $\$ 206$ & $\$ 412$ & $\$ 144$ & $\$ 129$ & $\$ 277$ \\
\hline March & $\$ 148$ & $\$ 67$ & $\$ 86$ & $\$ 22$ & $\$ 48$ & $\$ 49$ \\
\hline April & $\$ 248$ & $\$ 142$ & $\$ 38$ & $\$ 30$ & $\$ 10$ & $\$ 79$ \\
\hline May & $\$ 315$ & $\$ 301$ & $\$ 66$ & $\$ 111$ & $\$ 12$ & \\
\hline June & $\$ 413$ & $\$ 478$ & $\$ 250$ & $\$ 210$ & $\$ 337$ & \\
\hline July & $\$ 463$ & $\$ 571$ & $\$ 366$ & $\$ 322$ & $\$ 681$ & $\$ 210$ \\
\hline August & $\$ 452$ & $\$ 614$ & $\$ 423$ & $\$ 256$ & $\$ 594$ & $\$ 36$ \\
\hline September & $\$ 425$ & $\$ 383$ & $\$ 148$ & $\$ 140$ & $\$ 209$ & \\
\hline October & $\$ 358$ & $\$ 193$ & $\$ 72$ & $\$ 58$ & $\$ 15$ & \\
\hline November & $\$ 264$ & $\$ 109$ & $\$ 143$ & $\$ 6$ & $\$ 35$ & $\$ 50$ \\
\hline December & $\$ 152$ & $\$ 205$ & $\$ 260$ & $\$ 58$ & $\$ 76$ & $\$ 172$ \\
\hline Annual & $\$ 3,501$ & $\$ 3,541$ & $\$ 2,928$ & $\$ 1,449$ & $\$ 2,265$ & $\$ 1,130$ \\
\hline $\begin{array}{l}\text { Percent } \\
\text { Savings }\end{array}$ & $\mathbf{7 . 3 \%}$ & $\mathbf{6 . 8 \%}$ & $\mathbf{6 . 1 \%}$ & $\mathbf{2 . 8 \%}$ & $\mathbf{3 . 5 \%}$ & $\mathbf{2 . 0 \%}$ \\
\hline
\end{tabular}


Table 17. Energy Cost Savings for Two HLRs

\begin{tabular}{|c|c|c|c|c|c|c|}
\hline Month & Miami & Houston & Atlanta & Las Vegas & New York & Chicago \\
\hline January & $\$ 134$ & $\$ 273$ & $\$ 664$ & $\$ 93$ & $\$ 119$ & $\$ 258$ \\
\hline February & $\$ 103$ & $\$ 202$ & $\$ 412$ & $\$ 144$ & $\$ 129$ & $\$ 277$ \\
\hline March & $\$ 133$ & $\$ 56$ & $\$ 81$ & $\$ 22$ & $\$ 47$ & $\$ 49$ \\
\hline April & $\$ 235$ & $\$ 128$ & $\$ 29$ & $\$ 21$ & $\$ 9$ & $\$ 75$ \\
\hline May & $\$ 301$ & $\$ 283$ & $\$ 50$ & $\$ 97$ & $\$ 10$ & \\
\hline June & $\$ 399$ & $\$ 459$ & $\$ 230$ & $\$ 193$ & $\$ 315$ & \\
\hline July & $\$ 449$ & $\$ 552$ & $\$ 345$ & $\$ 305$ & $\$ 657$ & $\$ 199$ \\
\hline August & $\$ 438$ & $\$ 594$ & $\$ 401$ & $\$ 239$ & $\$ 569$ & $\$ 28$ \\
\hline September & $\$ 412$ & $\$ 366$ & $\$ 130$ & $\$ 125$ & $\$ 196$ & \\
\hline October & $\$ 345$ & $\$ 179$ & $\$ 65$ & $\$ 49$ & $\$ 11$ & \\
\hline November & $\$ 251$ & $\$ 98$ & $\$ 141$ & $\$ 5$ & $\$ 35$ & $\$ 50$ \\
\hline December & $\$ 139$ & $\$ 199$ & $\$ 258$ & $\$ 58$ & $\$ 76$ & $\$ 172$ \\
\hline Annual & $\$ 3,341$ & $\$ 3,390$ & $\$ \mathbf{2 , 8 0 6}$ & $\$ 1,352$ & $\$ 2,175$ & $\$ 1,107$ \\
\hline $\begin{array}{l}\text { Percent } \\
\text { Savings }\end{array}$ & $\mathbf{7 . 0 \%}$ & $\mathbf{6 . 5 \%}$ & $\mathbf{5 . 8 \%}$ & $\mathbf{2 . 6 \%}$ & $\mathbf{3 . 3} \%$ & $\mathbf{2 . 0 \%}$ \\
\hline
\end{tabular}

Another advantage and potential cost savings of reducing the ventilation rate for new construction or major retrofit is the reduction in the peak cooling load and required cooling capacity. The ability to downsize the cooling (and potentially heating) equipment represents a significant cost savings and impact on payback of HLR installation. The total cooling coil capacity reduction enabled by HLR operation in the medium office building is shown in Table 18 for each location. 
Table 18. Cooling Coil Capacity Reductions

\begin{tabular}{|c|c|c|c|}
\hline Location & $\begin{array}{c}\text { Climate } \\
\text { Zone }\end{array}$ & $\begin{array}{c}\text { Capacity } \\
\text { Reduction } \\
\mathbf{1 , 0 0 0} \text { Btu/hr (kW) }\end{array}$ & $\begin{array}{c}\text { Savings } \\
\mathbf{( \% )}\end{array}$ \\
\hline Miami, FL & 1A & $206(61)$ & $20 \%$ \\
\hline Houston, TX & 2A & $195(57)$ & $19 \%$ \\
\hline Atlanta, GA & 3A & $152(45)$ & $16 \%$ \\
\hline Las Vegas, NV & 3B & $95(28)$ & $9 \%$ \\
\hline New York, NY & 4A & $147(43)$ & $15 \%$ \\
\hline Chicago, IL & 5A & $189(55)$ & $18 \%$ \\
\hline
\end{tabular}

\subsection{Discussion}

The energy simulations show that energy and demand savings are achieved in all climate zones modeled. The energy saved is directly related to the reduction in ventilation airflow rate, duration of the reduction, and the temperature and humidity difference between the outdoor air and the HVAC supply air. The simulation results show that the highest energy savings are in climates with extreme hot or cold temperatures; however, the cost savings are very dependent on the utility tariffs and the tradeoffs between electricity and gas. Optimized control of the HLRs and timing of regeneration will improve the cost performance by minimizing peak demand charges.

Reducing ventilation rates during periods of high outdoor air humidity or pollution may improve some aspects of indoor air environmental quality depending on the severity of the outdoor air conditions and the effectiveness of the HVAC system at conditioning the outdoor air. The impact of ventilation air reduction on indoor air relative humidity was checked in the energy simulations and very little change was seen in the simulation results; however, actual results may vary depending on the dehumidification effectiveness of the HVAC system in high humidity conditions. Air contaminants are not modeled in EnergyPlus and were not included in this evaluation.

The largest cost impact on new construction or major retrofits (i.e., chiller replacement) may be the reduction in load and associated required cooling capacity required to meet the load. The energy simulations showed a reduction in peak cooling loads of $9 \%$ to $20 \%$. The results from these energy simulations are presented to show potential performance for one building type and system design. Actual energy performance with application of the HLR technology is very dependent on the building type, HVAC equipment design and efficiencies, building operation, location, and energy costs and each application should be analyzed for performance. 


\section{Conclusions}

The HLR technology was shown to control contaminants of concern below exposure limits with lower ventilation rates, which leads to energy savings. Energy savings as a percent of building load are highly dependent on the location, system types and efficiencies, and operating schedule. Cooling system energy savings were measured to range from $6 \%$ to $37 \%$ during the peak cooling month. Annual energy simulations were used to estimate the energy and energy cost performance in other locations for a single building type. Annual energy cost savings for a medium office building with one HLR unit ranged from roughly $\$ 1,130$ to more than $\$ 3,500$, assuming a reduction in the ventilation airflow rate of $20 \%$ of the design value. A potential advantage of the HLR technology is ability to reduce the required cooling capacity in new construction or in cooling system replacement projects. Energy simulations estimated capacity reductions between $9 \%$ and $20 \%$, depending on the location.

For retrofit applications, it is critical to find the correct application to achieve good performance. Lack of volume and controllability of the outdoor air was a key issue with many of the buildings reviewed in this project. The simulation results confirm that insufficient outdoor air will limit the potential for savings. For retrofit applications with undersized HVAC systems that are unable to meet indoor and ventilation load conditioning requirements, the HLR technology may reduce the need to upsize the HVAC system to meet the high loads. In these situations, the HLR technology may offset significant HVAC system upgrade costs, which may provide a quick return on investment. For new building designs, the HLR technology may allow for a downsized HVAC demand and distribution system, depending on the location and building ventilation requirements. The reduced HVAC system may offset a portion or even exceed the cost of the HLR system. Every application will be different and careful design and analysis should be conducted on each case to determine if the HLR technology is appropriate. 


\section{References}

ASHRAE 2013a. Energy Standard for Buildings Except Low-Rise Residential.

ANSI/ASHRAE/IES Standard 90.1-2013. Atlanta, GA.

ASHRAE 2013b. Ventilation for Acceptable Indoor Air Quality. ANSI/ASHRAE Standard 62.12013. Atlanta, GA.

ASHRAE 2016. Ventilation for Acceptable Indoor Air Quality. ANSI/ASHRAE Standard 62.12016. Atlanta, GA.

ASHRAE 2017. Thermal Environmental Conditions for Human Occupancy. ANSI/ASHRAE Standard 55-2017. Atlanta, GA.

Deru, Michael, Kristin Field, Daniel Studer, Kyle Benne, Brent Griffith, Paul Torcellini, Bing Liu, Mark Halverson, Dave Winiarski, Michael Rosenberg, Mehry Yazdanian, Joe Huang, Drury Crawley. 2011. U.S. Department of Energy Commercial Reference Building Models of the National Building Stock. NREL/TP-5500-46861. Golden, CO: National Renewable Energy Laboratory. https://www.nrel.gov/docs/fy11osti/46861.pdf.

DOE 2018a. "EnergyPlus Energy Simulation Software." Washington, D.C.: U.S. Department of Energy. www.energyplus.net.

DOE 2018b. 90.1 "Prototype Building Models." Washington, D.C.: U.S. Department of Energy. https://www.energycodes.gov/901-prototype-building-models-complete-package.

EIA. 2018. "National Energy Retail Cost Data." Washington, D.C.: Energy Information Administration. www.eia.gov.

enVerid. 2017. "enVerid Data Sheet HLR 1000-M.” Westwood, MA: enVerid Systems, Inc. www.enVerid.com.

EPA. 2013. "National Ambient Air Quality Standards (40 CFR Part 50)." Washington, D.C.: Environmental Protection Agency. https://www.epa.gov/criteria-air-pollutants/naaqs-table.

Granade, Hannah Choi, Jon Creyts, Anton Derkach, Philip Farese, Scott Nyquist, and Ken Ostrowski. 2009. "Unlocking Energy Efficiency in the U.S. Economy." McKinsey \& Company. http://www.uky.edu/ tmute2/GEI-Web/password-protect/GEI-readings/US-energy-efficiencyabatement-full-report.pdf.

NIOSH (The National Institute for Occupational Safety and Health). 2018. "National Institute for Occupational Safety and Health Pocket Guide to Chemical Hazards: Formaldehyde."

Washington, D.C.: Centers for Disease Control and Prevention. http://www.cdc.gov/niosh/npg/npgd0293.html.

OEHHA (California Office of Environmental Health Hazard Assessment). 2018. "California Office of Environmental Health Hazard Assessment Chemical Database." https://oehha.ca.gov/chemicals. 
OSHA (Occupational Safety \& Health Administration). 2018. "Occupational Safety and Health Administration. Limonene chemical sampling." Washington, D.C.: U.S. Department of Labor. https://www.osha.gov/dts/sltc/methods/partial/pv2036/2036.html.

WHO. 2010. WHO guidelines for indoor air quality: selected pollutants. Denmark: World Health Organization Europe. https://apps.who.int/iris/handle/10665/260127. 


\section{Appendix A-Demonstration Site Checklist}

Table A-1. Site Information

\begin{tabular}{|c|c|}
\hline Building Name & \\
\hline Building Primary Activity & \\
\hline Location (city, state) & \\
\hline Building Area (ft $\left.{ }^{2}\right)$ & \\
\hline Weekly Operation Hours & \\
\hline
\end{tabular}

Table A-2. High-Level Criteria

\begin{tabular}{|c|c|}
\hline $\begin{array}{c}\text { Owner is ready to move, } \\
\text { interested in making the } \\
\text { demonstration a success }\end{array}$ & \\
\hline $\begin{array}{c}\text { Building staff will be accessible to } \\
\text { the demonstration team }\end{array}$ & \\
\hline $\begin{array}{c}\text { Access to return air ducts and } \\
\text { space to install the HLR system }\end{array}$ & \\
\hline $\begin{array}{c}\text { Outdoor air dampers are operable } \\
\text { and can be controlled by the HLR } \\
\text { system }\end{array}$ & \\
\hline $\begin{array}{c}\text { Total airflow rate > 10,000 cfm } \\
\text { total airflow rates }\end{array}$ & \\
\hline $\begin{array}{c}\text { Outdoor airflow rates }>20 \% \text { of } \\
\text { with ventilation operation }\end{array}$ & \\
\hline $\begin{array}{c}\text { Greater than } 50 \text { hours per week } \\
\text { with }\end{array}$ & \\
\hline $\begin{array}{c}\text { Minimal or no use of manually } \\
\text { operable windows }\end{array}$ & \\
\hline $\begin{array}{c}\text { Other ventilation load reduction } \\
\text { strategies implemented (DCV, } \\
\text { ERV, and so on) }\end{array}$ & \\
\hline $\begin{array}{c}\text { Building automation system } \\
\text { allows link to the HLR system } \\
\text { control platform }\end{array}$ & \\
\hline
\end{tabular}


Table A-3. Systems-Related Criteria

\begin{tabular}{|c|c|}
\hline Chilled water metering available & \\
\hline Whole building electrical meter & \\
\hline Electrical submetering & \\
\hline $\begin{array}{c}\text { Up-to-date mechanical drawings } \\
\text { available }\end{array}$ & \\
\hline $\begin{array}{c}\text { No large HVAC maintenance or } \\
\text { replacement plans in the next } \\
\text { year }\end{array}$ & \\
\hline $\begin{array}{c}\text { All mechanical systems } \\
\text { operational }\end{array}$ & \\
\hline $\begin{array}{c}\text { Space/AHU relationship known } \\
\text { Available TAB report (vintage) }\end{array}$ & \\
\hline $\begin{array}{c}\text { Available OA/Exhaust } \\
\text { measurements }\end{array}$ & \\
\hline $\begin{array}{c}\text { Building ventilation challenges } \\
\text { (known IAQ issues, and so on) }\end{array}$ & \\
\hline $\begin{array}{c}\text { Available occupancy and/or } \\
\text { people count }\end{array}$ & \\
\hline \begin{tabular}{c} 
Available trend logs from BAS \\
\hline
\end{tabular} & \\
\hline
\end{tabular}

Table A-4. Utilities-Related Criteria

\begin{tabular}{|c|c|}
\hline Site has high utility rate & \\
\hline $\begin{array}{c}\text { Site has demand charges or other } \\
\text { incentives for peak load reduction }\end{array}$ & \\
\hline $\begin{array}{c}\text { Site potentially has access to } \\
\text { rebates for installation }\end{array}$ & \\
\hline
\end{tabular}




\section{Appendix B-Uncertainty Calculations}

Table B-1. Measurement Uncertainties

\begin{tabular}{|l|c|l|}
\hline Measurement & Uncertainty & Notes \\
\hline Dry bulb temperature & $\pm 0.5^{\circ} \mathrm{C}$ & \\
\hline Dew point temperature & $\pm 0.5^{\circ} \mathrm{C}$ & $\begin{array}{l}\text { Used only for UMH Wellness } \\
\text { Center }\end{array}$ \\
\hline Relative humidity & $\pm 5 \%$ & $\begin{array}{l}\text { Used only for Morgan Stanley } \\
\text { headquarters }\end{array}$ \\
\hline $\begin{array}{l}\text { Chiller water supply and return } \\
\text { temperatures }\end{array}$ & $\pm 0.1^{\circ} \mathrm{C}$ & $\begin{array}{l}\text { Used only for Morgan Stanley } \\
\text { headquarters }\end{array}$ \\
\hline Chilled water flow rate & $\pm 1 \%$ of value & $\begin{array}{l}\text { Used only for Morgan Stanley } \\
\text { headquarters }\end{array}$ \\
\hline Chilled water energy & $\pm 5 \%$ of value & $\begin{array}{l}\text { Used only for UMH Wellness } \\
\text { Center }\end{array}$ \\
\hline
\end{tabular}




\section{Appendix C-Utility Tariffs}

Utility tariffs used for annual energy simulations for each location included in this study. Not all fixed fees are included but they would not affect the energy cost savings, since they would be the same for all cases. Taxes are not included and would slightly increase the energy cost savings (and negative energy cost savings).

\section{$\underline{\text { Miami, Florida (Climate Zone 1A) }}$}

- Electric utility: Florida Power and Light GSD-1 Rate

○ $\$ 9.54 / \mathrm{kW}$ demand charge

○ $\$ 2.215 / \mathrm{kWh}$ energy charge

○ $₫ 0.086 / \mathrm{kWh}$ storm charge

○ $\$ 0.48 / \mathrm{kW}$ conservation charge

○ $\$ 0.70 / \mathrm{kW}$ capacity charge

○ $£ 0.105 / \mathrm{kWh}$ environmental charge

○ $\notin 2.631 / \mathrm{kWh}$ fuel charge.

- Natural gas utility: Florida City Gas GS-25K Rate

○ $\$ 0.32696 /$ therm.

\section{Houston, Texas (Climate Zone 2A)}

- Electric utility: CenterPoint Energy Medium Non-Residential LSP POLR

○ \$26.8181 flat monthly charge

○ $\$ 5.66567 / \mathrm{kW}$ demand charge

○ \$ 0.079973/kWh energy charge.

- Natural gas utility: CenterPoint Energy
○ Jan: $\$ 0.57178 /$ therm
○ Feb: $\$ 0.56471 /$ therm
○ Mar: \$0.56472/therm
○ Apr: \$0.56476/therm
○ May: $\$ 0.56477 /$ therm
○ Jun: $\$ 0.56476 /$ therm
○ Jul: \$0.56475/therm
○ Aug: \$0.55227/therm
○ Sep: $\$ 0.55167 /$ therm
○ Oct: $\$ 0.55165 /$ therm 
○ Nov: $\$ 0.55158 /$ therm

○ Dec: $\$ 0.55156 /$ therm.

\section{$\underline{\text { Atlanta, Georgia (Climate Zone 3A) }}$}

- Electric utility: Georgia Power PLM-11

○ Monthly service charge: $\$ 19.00$

- All consumption $(\mathrm{kWh})$ not greater than 200 hours times the billing demand:

- First 3,000 kWh: $\varnothing 11.2561 / \mathrm{kWh}$

- Next 7,000 kWh: $₫ 10.3091 / \mathrm{kWh}$

- Next 190,000 kWh: $₫ 8.8885 / \mathrm{kWh}$

- Over 200,000 kWh: $₫ 6.8955 / \mathrm{kWh}$

- All consumption ( $\mathrm{kWh}$ ) in excess of 200 hours and not greater than 400 hours times the billing demand: $₫ 1.1437 / \mathrm{kWh}$

- All consumption (kWh) in excess of 400 hours and not greater than 600 hours times the billing demand: $₫ 0.8606 / \mathrm{kWh}$

- All consumption (kWh) in excess of 600 hours times the billing demand: $\varnothing 0.7486 / \mathrm{kWh}$.

- Natural gas utility: Georgia Natural Gas

○ $\$ 1.99+\$ 6.95$ monthly service charge

○ $\$ 1.58 /$ therm.

\section{Las Vegas, Nevada (Climate Zone 3B)}

- Electric utility: Nevada Power LGS-1

- $\$ 0.06676 / \mathrm{kWh}$ energy charge

- $\$ 4.35 / \mathrm{kW}+\$ 4.22 / \mathrm{kW}$ demand charge.

- Natural gas utility: Southwest Gas

- \$160 monthly service charge

○ $\$ 0.40851 /$ therm.

\section{New York, New York (Climate Zone 4A)}

- Electric utility: Consolidated Edison

- $\$ 27.61 / \mathrm{kWh}$ summer on peak energy charge

$\circ \quad \not 1.01 / \mathrm{kWh}$ summer off peak energy charge

○ $\not 13.60 / \mathrm{kWh}$ winter on peak energy charge 
○ $\notin 1.01 / \mathrm{kWh}$ winter off peak energy charge

○ Summer: June 1-September 30

○ On peak: weekdays 08:00-22:00.

- Natural gas utility: Consolidated Edison

- $\$ 30.45 /$ therm for $1-3$ therms

○ $\$ 0.7462 /$ therm for next 87 therms

- $\$ 0.4229 /$ therm for next 160 therms

○ $\$ 0.2774 /$ therm for next 2,750 therms

○ $\$ 0.1456 /$ therm above 3,000 therms.

\section{Chicago, Illinois (Climate Zone 5A)}

- Electric utility: Commonwealth Edison

○ $\$ 0.07159 / \mathrm{kWh}$ summer energy charge

○ $\$ 0.07465 / \mathrm{kWh}$ winter energy charge

- $\$ 6.47 / \mathrm{kW}$ year-round demand charge

○ Summer: June 1-September 30.

- Natural gas utility: Nicor Gas
○ Jan: $\$ 0.42 /$ therm
○ Feb: $\$ 0.41 /$ therm
○ Mar: \$0.39/therm
○ Apr: $\$ 0.39 /$ therm
○ May: \$0.41/therm
○ Jun: $\$ 0.43 /$ therm
○ Jul: $\$ 0.37 /$ therm
○ Aug: \$0.35/therm
○ Sep: $\$ 0.33 /$ therm
○ Oct: $\$ 0.33 /$ therm
○ Nov: $\$ 0.33 /$ therm
○ Dec: $\$ 0.33 /$ therm. 